تصميم ويناء اختبارات لقياس بعض المهارات الأساسية للاعبي أندية الدوري الممتاز العراقي في خماسي كرة القدم

م •م عمار شهاب أحمد الجبوري أ ·م.د مكي محمود حسين الراوي'

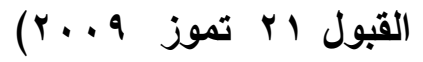

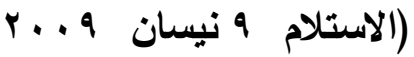

\title{
villill
}

نظراً لحداثة لعبة خماسي كرة القدم، ومن خلال متابعة الباحثان للأدبيات التي كتبت عن هذه اللعبة من كتب وبحوث وعلى حد علم الباحثان لا نوجد إختبارات خاصة لقياس المهارات الأساسية للعبة خماسي كرة القدم.

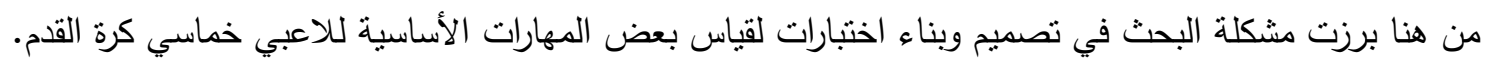

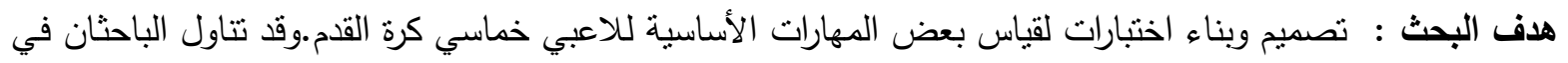
الإطار النظري بناء الاختبارات المهارية والمهارات الأساسية في خماسي كرة القدم ودراسات سابقة تم عرضها ومناقشتها.

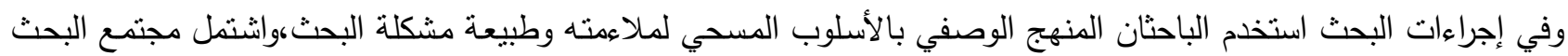

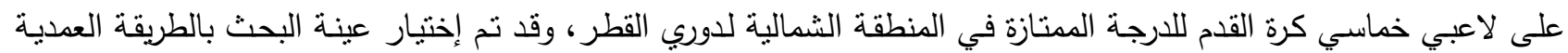

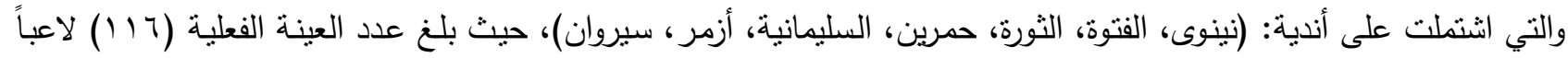

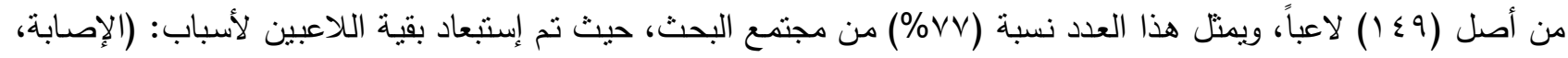

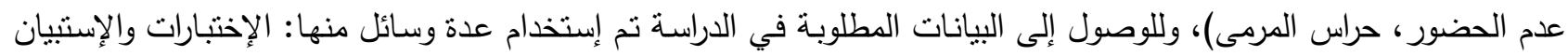

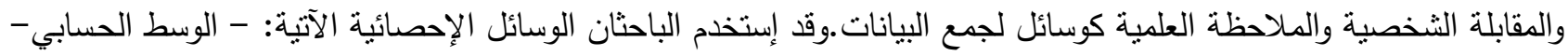
الانحراف المعياري- معامل الارتباط البسيط لـ(بيرسون)- إختبار (t) لعينات المستقلة- قانون النسبة المئوية- معامل الإلنواءئإختبار مربع كاي.

ومن أبرز النتائج التي توصل إليها الباحث ما بأني:

ا ـ نتيجةً لأتباع الوسائل العلمية الخاصة ببناء الاختبارات تم الحصول على مجموعة اختبارات مهارية للاعبي خماسي كرة القدم تتمتع بمعاملات علمية جيدة من صدق وثبات وموضوعية وتوزيع طبيعي وهي:

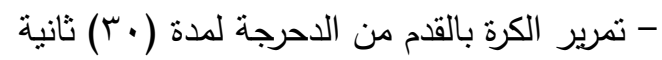

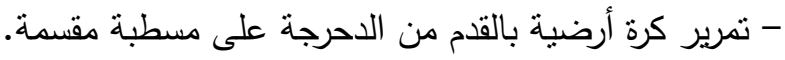
- تمرير الكرة بالقدم على الدوائر المتداخلة والمرسومة على الحئ الحائط من الكرات الثابتة. - التهديف من الحركة على التقسيمات المتداخلة والمرسومة داخل الهدف. - التهديف من الكرات الثابتة على ستة تقنيف التهيمات.

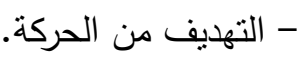
- التهديف من الحركة من الكرة القادمة من جانب الرجل المسبطرة. - التهديف من الحركة من الكرة القادمة من الخلف.

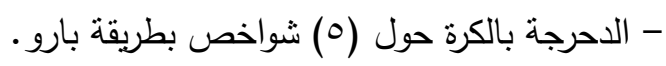

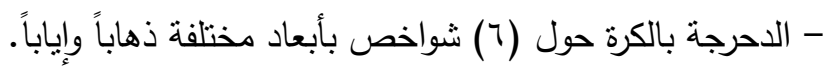

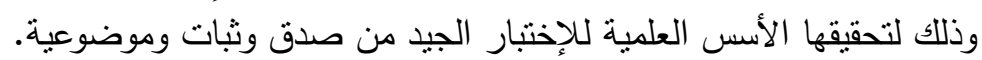

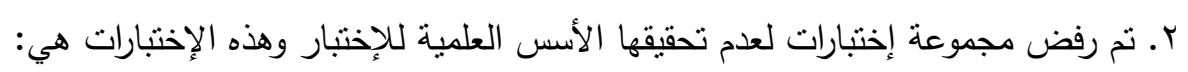
- الدحرجة بالكرة حول (^) شواخص بأبعاد مختلفة ذهاباً وإياباً. 


$$
\begin{aligned}
& \text { تصميم وبناء اختبارات لقياس بعض المهارات الأساسية للاعبي أندية الدوري الممثاز العراقي .... } \\
& \text { - الاحرجة بالكرة حول منلث منساوي الأضلاع. } \\
& \text { - التهديف من الكرات الثابتة. } \\
& \text { - الاحرجة بالكرة. } \\
& \text { - الاحرجة بالكرة حول (9) شوالكرة. }
\end{aligned}
$$

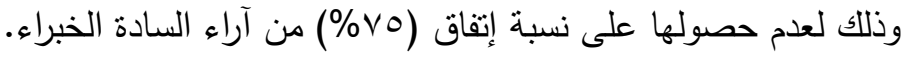

$$
\begin{aligned}
& \text { r. الاختبارات المعتمدة تتوزع توزيعاً طبيعياً. } \\
& \text { وكانت أهم التوصيات: } \\
& \text { ا ـ إعتماد الإختبارت التي حققت الأسس العلمية من صدق وثبات وموضوعية وتوزيع طبيعي في تقويم المهارات الأساسية للاعبي }
\end{aligned}
$$

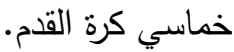

$$
\begin{aligned}
& \text { r.تعميم نتائج الإختبارات إلى الأندية المستفيدة من البحث. } \\
& \text { r. إجراء بحوث مشابهة على عينات أخرى وعلى مناطق جغرافية أخرى. } \\
& \text { ؟ .وضع درجات ومستويات معيارية للاختبارات المعتمدة. }
\end{aligned}
$$

\section{Designing and Constructing Tests to measuring Some offensive skill-tests}

\section{for Futsal Players}

\section{Asst.Prof.Dr. Maki .M. Hussein Al-Rawi Asst. Lecturer. A. Shihab Ahmmed}

\footnotetext{
ABSTRACT

As Futsal is a new sport and through reviewing the literature written about the game and- as far as the researcher knows- no tests for measuring futsal basic skills are available. Thus; the research problem has emerged to establish a number of tests to measure certain skills of futsal game.

Research objective

- Establishing a number of tests to measure certain basic skills for Futsal players.

The researcher has tackled -within the theoretical framework- the establishment of basic skill tests in futsal as well as discussing and displaying previous studies.

Within the research measures; the researcher has followed the survey descriptive methodology for its convenience with the nature of the research problem. This methodology-by such a technique- is considered one of those fact-finding methods that induce the required results for solving problems in a certain society.

Research population has included Futsal first-class players in the Iraqi tournament $\backslash$ North region and the subjects have been chosen intentionally including the following clubs: Ninevah ,Alfutwa, Himreen, Suleimaniya, Azmar\& Sirwan.

Actual number of subjects was (116) out of (149) representing (\%77) of the research population, other players were excluded for reasons such as injury, absence and goalkeepers.

In order to attain the required data ; the researcher has applied several tools such as content analysis to determine Futsal basic skills. Skills demonstrated by analysis are: Shooting, dribbling, Passing, Stopping, corner Kick, side Kick, distopping, Dodging as well as other means for collecting data such as tests, questionnaire, interviews and scientific observation.

The researcher has employed the following statistical tools:

arithmetic mean

standard deviation

Person's simple correlation coefficient

t-Test for independent samples

Percentage

Modified T-scores
} 
Chi-square test (goodness of fit)

The most prominent results attained by the researcher are as follows:

1. Tests were accepted as having met the scientific bases for good test, including validity reliability and objectivity.

- Passing the ball with the foot from dribbling for $30 \mathrm{sec}$.

- Shooting from movement on the overlapped divisions drawn inside the goal.

- Shooting from stable balls on six divisions.

- Shooting from movement.

- Shooting from movement for a ball coming from the controlling leg side.

- Shooting from movement for a ball coming from the back.

- Dribbling the ball around (5) stakes according to Barrow method.

- Dribbling the ball around (6) stakes with different dimensions back \& forth.

- Side shoots on a curved goal

- Passing a ground ball by the foot from dribbling on a divided bench.

- Passing the ball by foot on the overlapped circles drawn on the wall from stable balls.

- Stifling ground ball by the feet from the movement position, then passing it towards the goals on both sides.

2. Unaccepted tests for obtaining less than $\% 75$ of specialists' approval.

- Side shoots on 3 goals

- Dribbling the ball around 8 stakes with different dimensions back \& forth.

- Dribbling the ball around an equilateral triangle.

- Scoring from stable balls

- Dribbling the ball

- Dribbling the ball around (9) stakes.

5. Approved test are distributed normally.

The research has presented a number of recommendations; the most important of which are as follows:

1. Adopting tests that meet the scientific bases include validity, invariability, and objectivity.

2. Circulating tests' findings upon sport clubs that benefits from the research.

3. Performing similar researches on other topics.

4. Performing similar researches on other geographical areas.

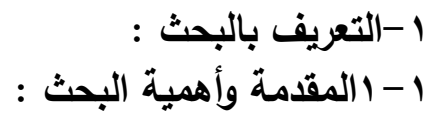

تعد لعبة خماسي كرة القدم من الألعاب التي بدأت نتنشر حديثاً في بلدان العالم بسرعة كبيرة وفي القارات كافة،

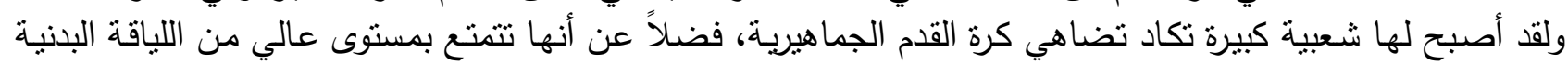

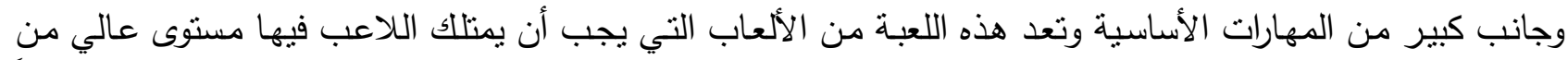

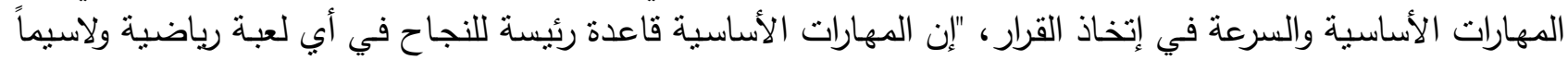

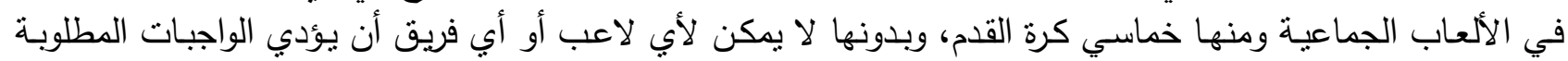

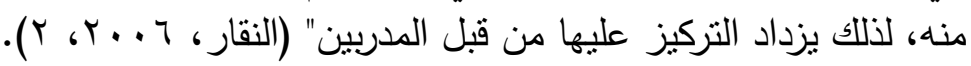

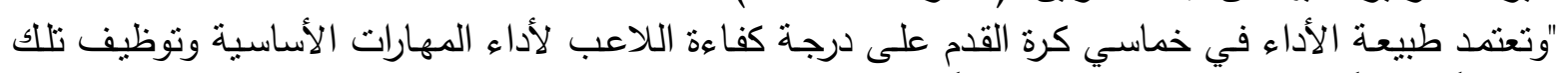

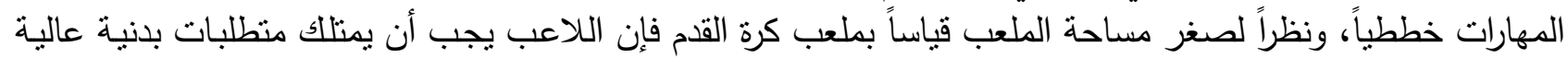

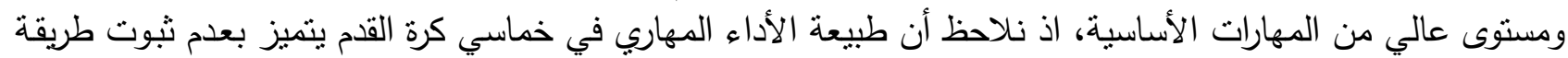

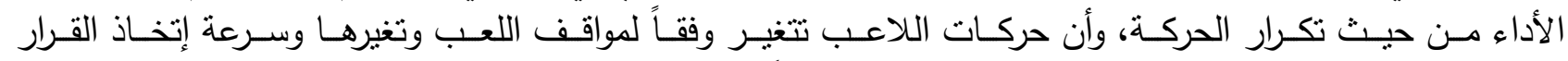
الصحيح".WWW. HOLISTICSOCCR. COM)،ونظراً لأهمية الإختبارات والمقاييس في جميع الألعاب الرياضية

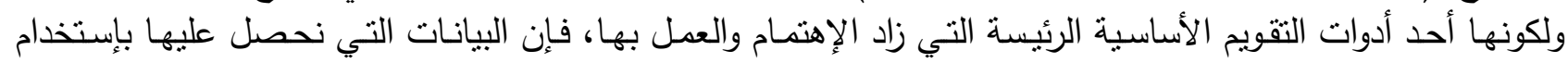

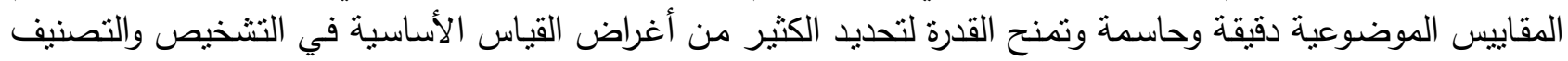
والتبوء والبحث العلمي والتي تخدم العاملين في المجـال الرياضي، وعن طريف هذه الإختبارات يمكن تقويم المنـاهج 


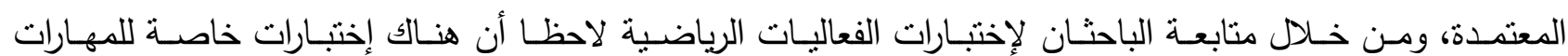

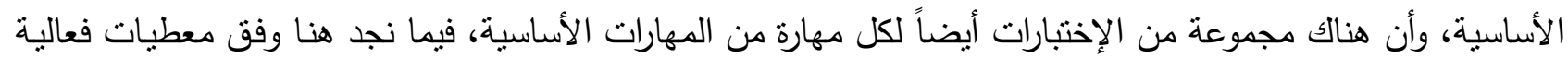

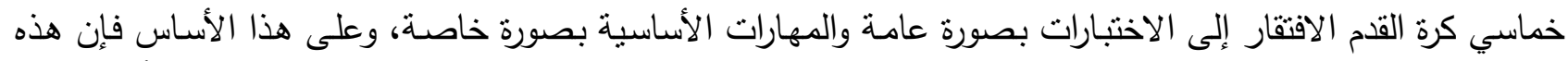

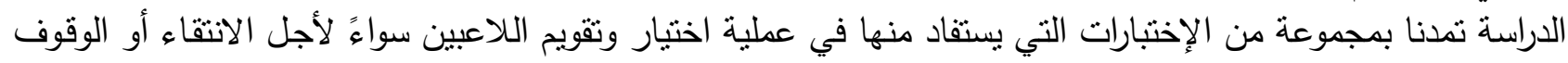

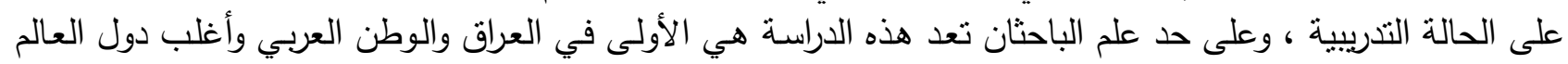

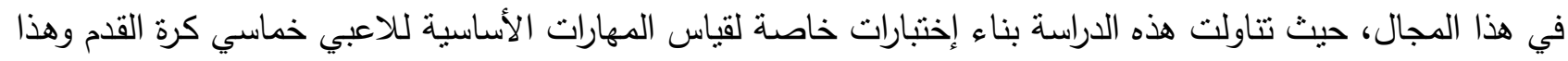

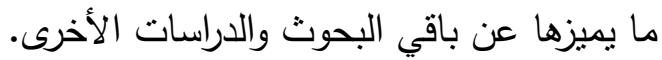

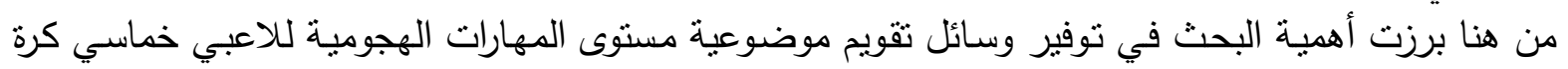

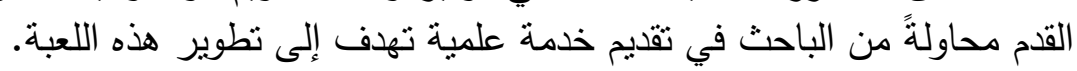

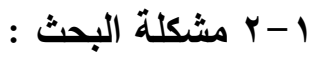

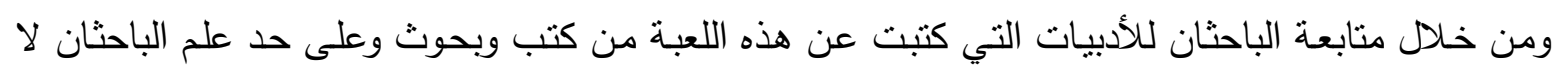

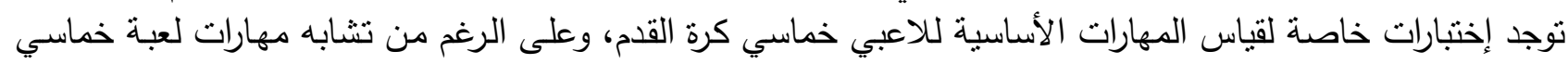

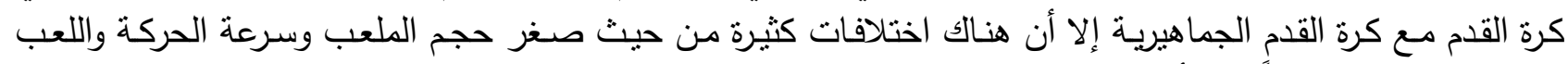

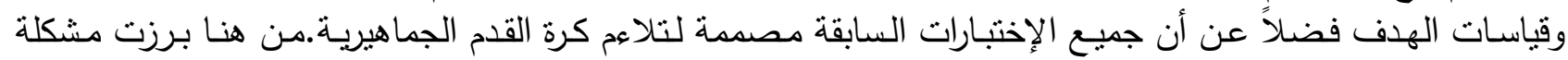

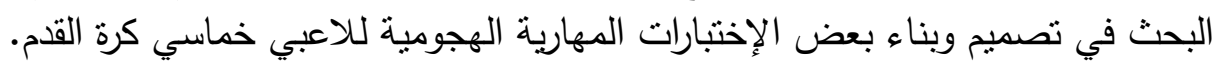
:

1-r-1 أصميم وبناء اختبارات لقياس بعض المهارات الأساسية للاعبي أندية الدوري الممتاز العراقي بخماسي كرة القدم

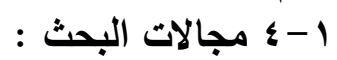
1- ا- - الدجال البشري: لاعبوا أندية الدرجة المثتازة في المنطقة الثمالية من القطر العراقي وهذه الأندية هي: (نينوى،

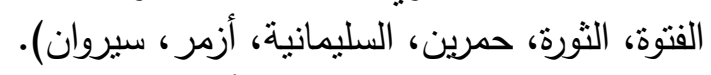

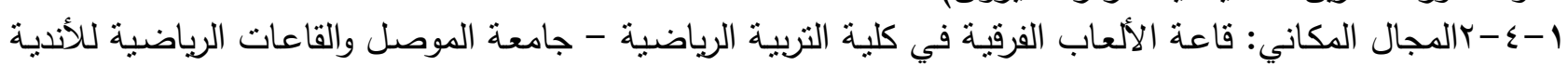

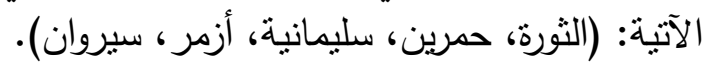

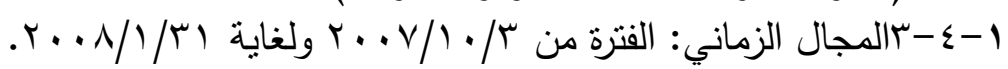

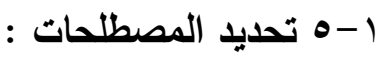

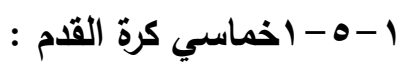

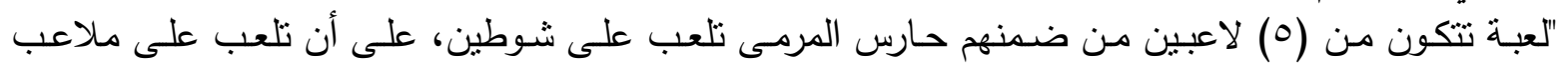

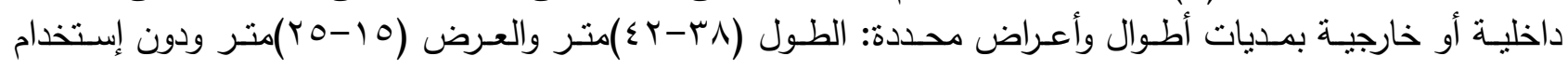

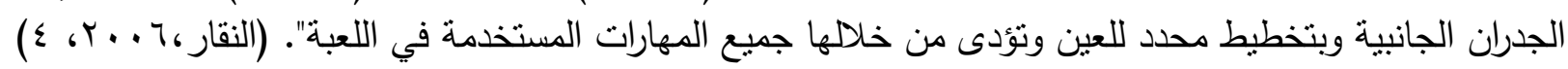

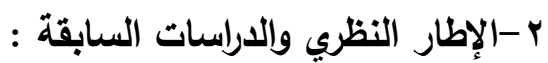

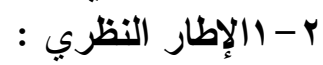

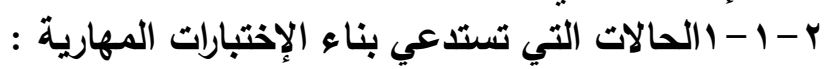
"هنالك بعض الحالات التي تستدعي بناء إختبارات جديدة لإستخدامها في قياس المهارات في اللعب، ومن

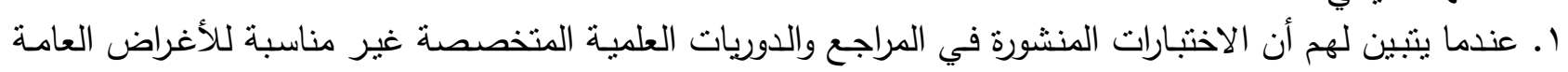

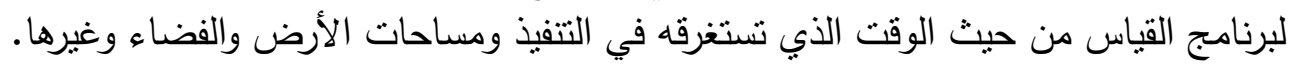

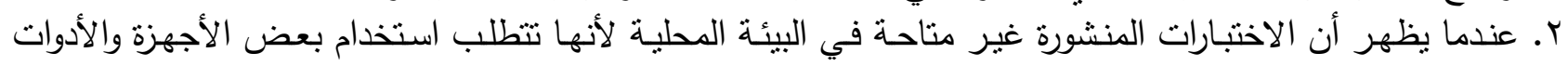

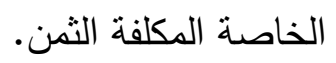
r. في الحالات الني لا تذكر فيها المصنادر بيانات كافية عن الاختبار مثل الغرض منه وطريقة الأداء وتعليهات

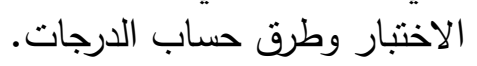
ع. عندما يفقد الاختبار ما بشير إحصائياً إلى صدقه وثباته. 
ه. الحاجة إلى ثقنين بعض وسائل القياس الموضوعية للإفادة منها في تقويم الأداء في بعض الأنشطة الرياضية.

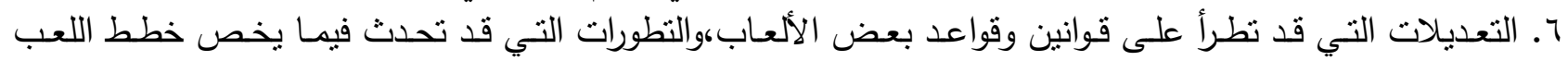
وأسـاليب التدريب، ومـا يستجد من فعاليات رياضية جديدة، كذلك يستلزم العهل على تلى تطوير وسـائل القياس المتاحسة

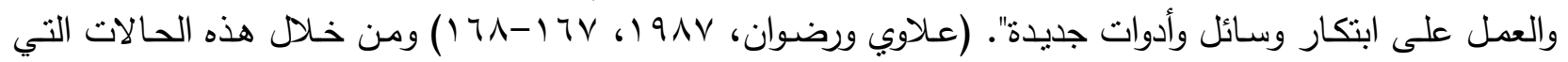

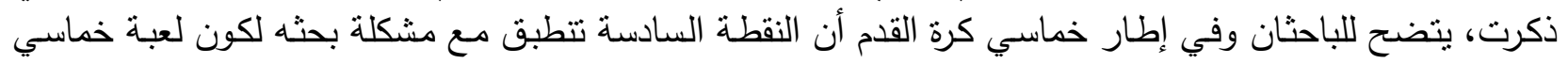
كرة القدم لعبة حديثة في الإتحاد العراقي.

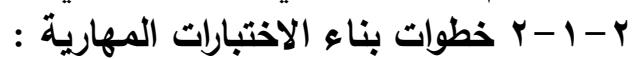

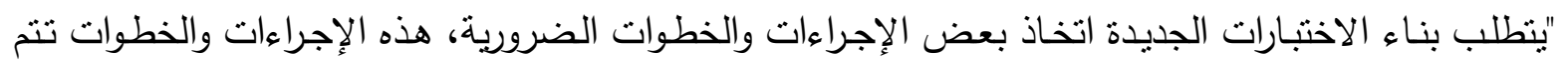

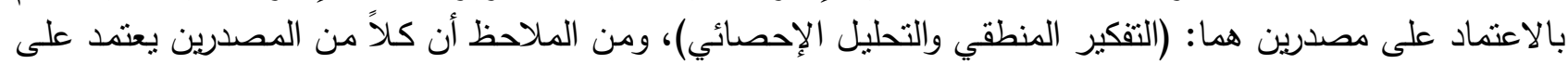

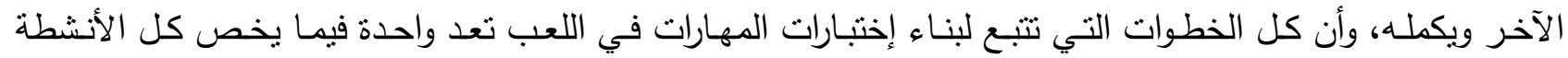

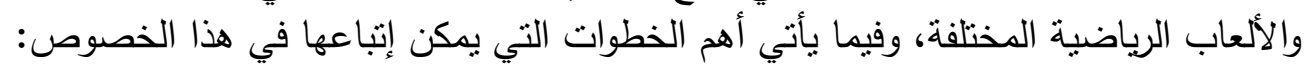
- تحليل المهارة المطلوب قياسها. - إختيار وحدات الإختبار التي تقيس المهارة المهارات المتنقق عليها.

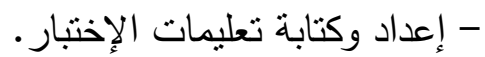
- إختيار الأفراد الذي سيطبق عليمات عليهم الإختبار .

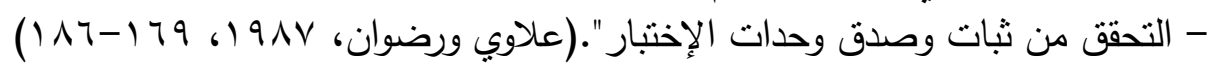

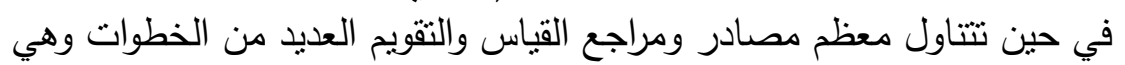

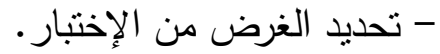

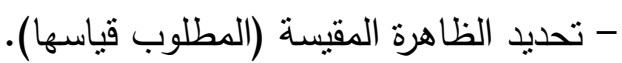
- تحديد الظاهرة وإعداد جدول مواصفات.

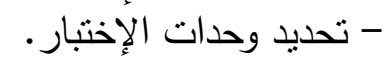

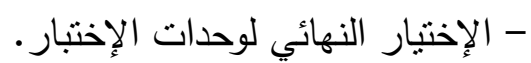
- إعداد شروط وتعليمات تطبيق الإختبار .

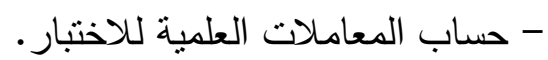
- إعداد الشروط والتعليمات النهائية للاختبار . - تطبيق الإختبار وإعداد المعايير -

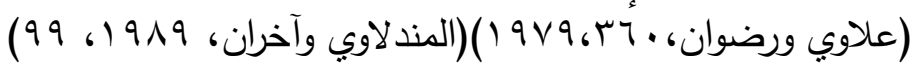

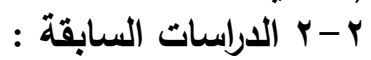

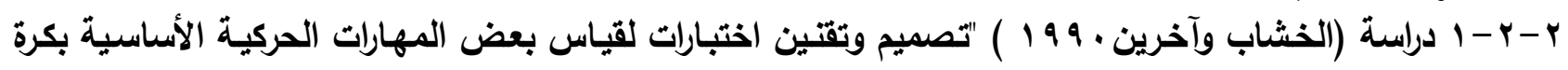

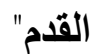

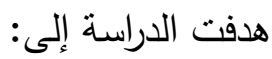
- تصميم اختبارات مقننة: - إيجاد مستويات معيارية استخدم الباحثون المنهج الوصفي لحل مشكلة البحث ، واعتمدوا على المقابلة الثخصية والملاحظة والاختبارات

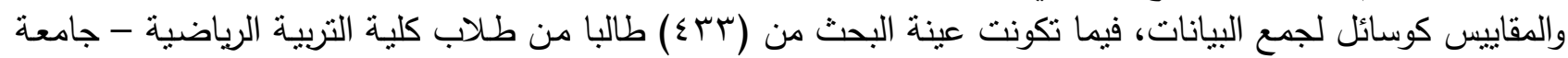

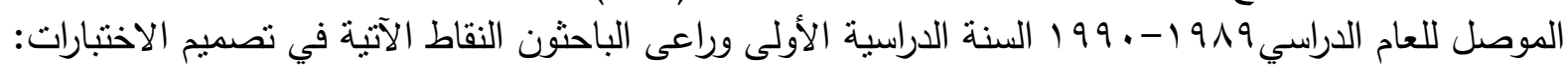

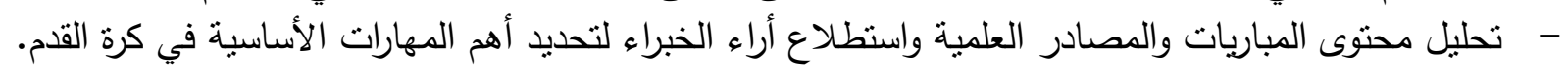

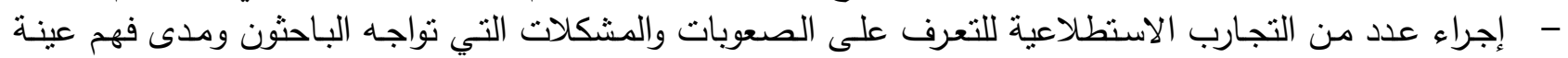
البحث للاختبارات ومدى مناسبة الاختبارات لعينة البحث.

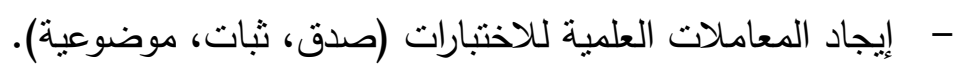

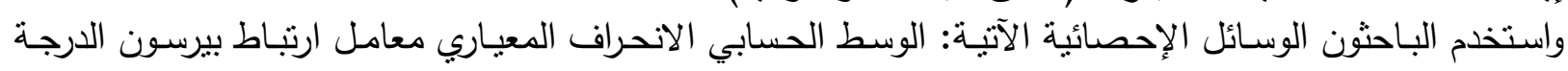
المعيارية 


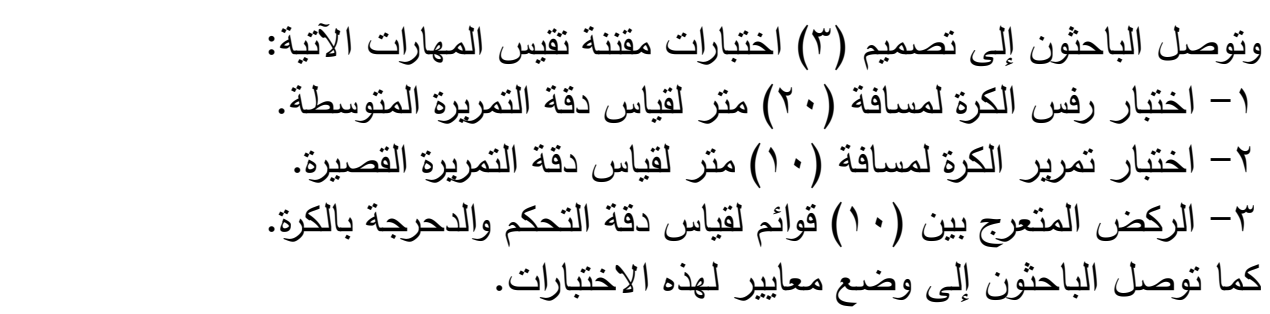

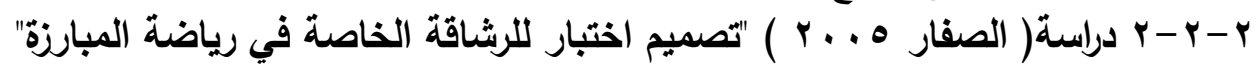

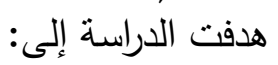

- تصميم اختبار يقيس الرشاقة الخاصة لحركة القدم والتقهق في رياضة المبارزة. -وضع درجات ومستويات معيارية للاختبار لطلاب السنة الدراسية الثالثة لكلية التربية الرياضية - جامعة الموصل. واستخدم الباحث المنهج الوصفي لحل مشكلة دارئة البحث.

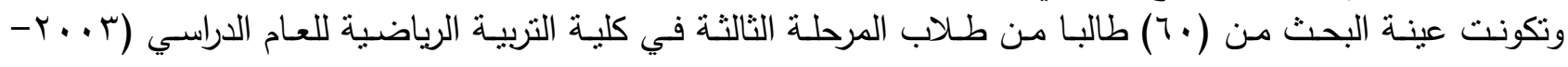

واستخدم الباحث الاستبيان والاختبار كوسيلة لجمع البيانات.واتبع الخطوات الآتية في تصميم الاختبارات: $\cdot(r . . \varepsilon$ ا ـ عرض الاختبارات على مجموعة من الخبراء.

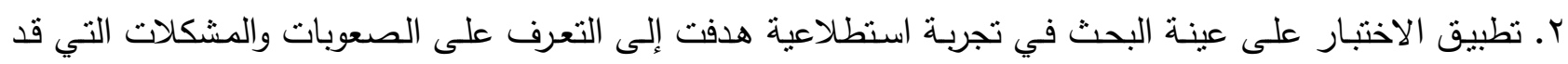

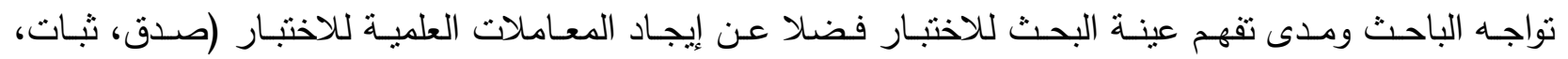
موضوعية). واستخدم الباحث الوسائل الإحصائية الآتية:

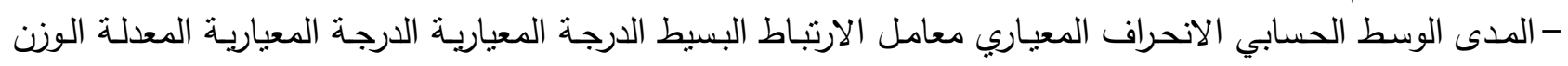

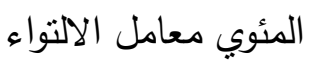

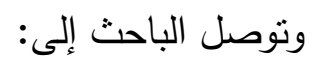

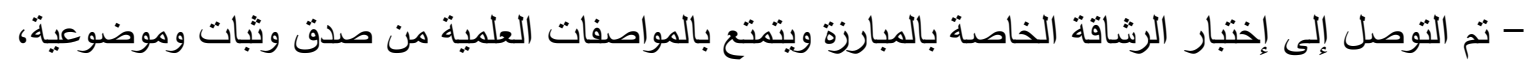

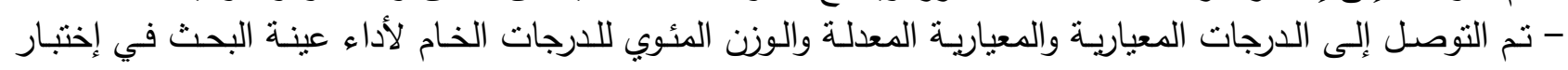
الرشاقة.

- إن أغلب طلاب عينة البحث كانوا من المستوى المتوسط.

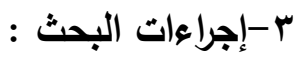

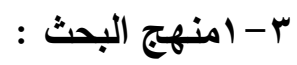

استخدم الباحثنان المنهج الوصفي بالأسلوب المسحي لملاءمته وطبيعة مشكلة البحث، حيث "يعد هذا المنهج

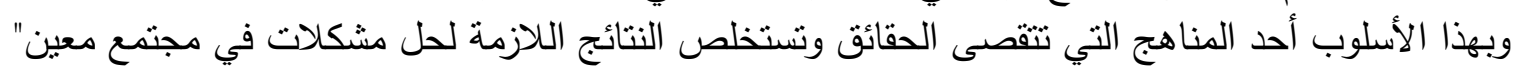

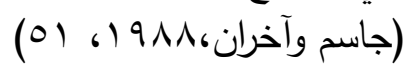

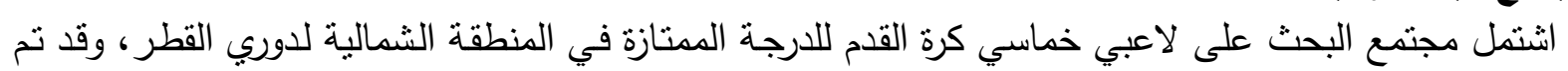
: r-r

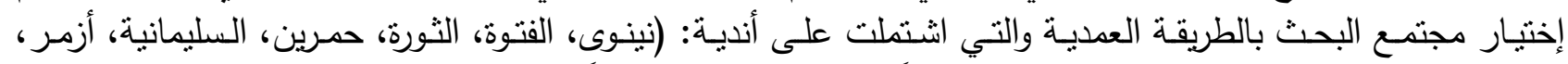

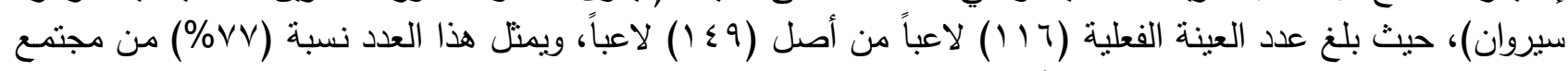

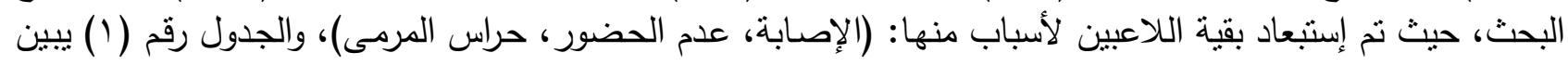
توزيع عينة البحث على الأندية المذكورة.

\section{الجدول رقم (1) يبين توزيع عينة البحث على الأندية}




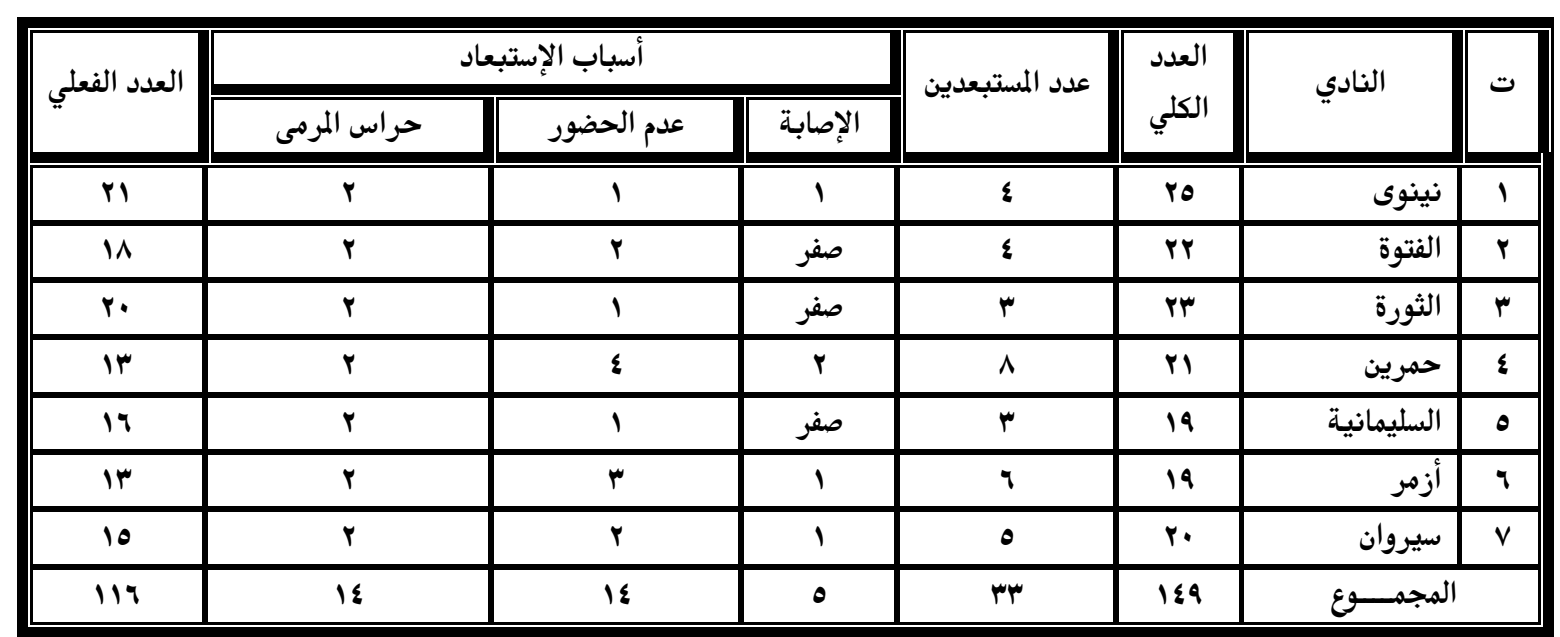

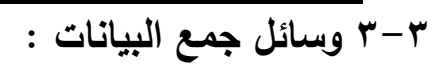
من أجل الحصول على البيان : النتائج التي تخدم البحث، إستعان الباحثان بعدد من وسائل جمع البيانات وهي:

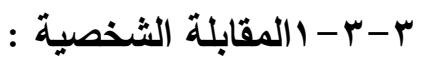
تم بإجراء المقابلات الشخصية مـع مجموعة من الخبراء والمتخصصين' في مجال كرة القدم والقياس والتقويم

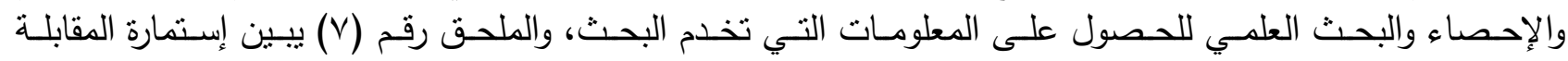

أعدت استمارة استبيان وزعت على مجلى مجوعة مـن الخبراء والمختصين " في مجال كرة القدم والقياس والتقويم للحصول على نسب إتفاق حول الإختبارات المقترحة، وسوف يتم شرح هذا الإجراء في تفاصبل بناء الإختبارات.

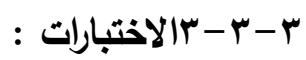

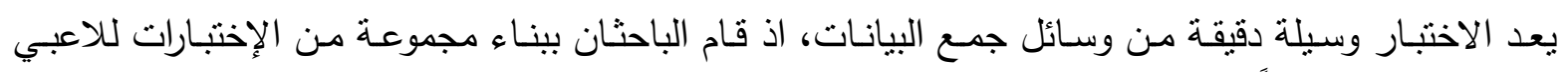

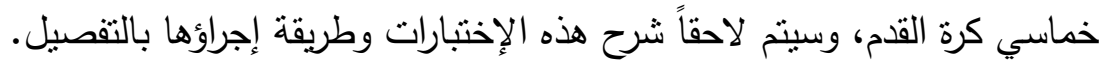

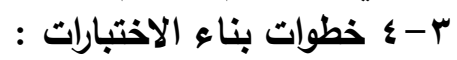

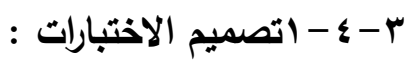
بعد الحصول على أهم المهارات الأساسية للعبة كرة القدم داخل الصالات(من خلال الملاحظة العلمية وتحليل

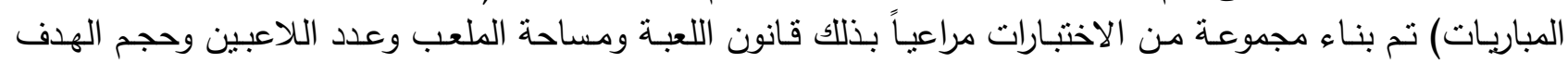

\begin{tabular}{|c|c|}
\hline تربية محاصيل التدريب الرياضية & 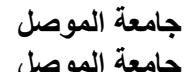 \\
\hline القياس والتقويم & 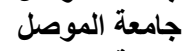 \\
\hline القياس والتقويم & ل \\
\hline القياس والتقويم & 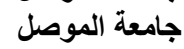 \\
\hline القياس والتقويم & 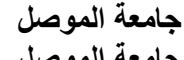 \\
\hline البايوميكاتيك & ل \\
\hline علم التدر & المو \\
\hline التعلم الحركي & المو \\
\hline القياس والتقويم & لة الموصل \\
\hline القياس والتقويم & ة الموصل \\
\hline القياس والتقويم & الموص \\
\hline علم التدريب الرياض & الموة - - المو \\
\hline القياس والتقويم & لموه \\
\hline القياس والتقويم & الموصل \\
\hline القياس والتقويم & \\
\hline القياس والتقويم & الموصل \\
\hline
\end{tabular}

كلية التربية الرياضية

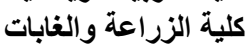
كلية التربية الرياضية الربابة والثابية كلية التربية الرياضية الرياضية كلية التربية الرياضية الرياضية كلية التربية الرياضية الرية كلية التربية الرياضية الرياضية كلية التربية الرياضية الرياضية كلية التربية الرياضية الترية كلية التربية الرياضية الرية كلية التربية الرياضية الرياضية كلية التربية الرياضية الرياضية كلية التربية الرياضية الرية كلية التربية الأسناسية كلية التربية الرياضية الاضية كلية التربية الرياضية الرياضية كلية التربية الرياضية الرية كلية التربية الأساسية
أستاذ دكتور أستاذ دكتور أستاذ دكتور أستاذ دكتور أستاذ مساعد دكتور أستاذ مساعد دكتور أستاذ دكتور أستاذ دكتور أستاذ دكتور أستاذ دكتور أستاذ دكتور أستاذ دكتور أستاذ مساعد دكتور أستاذ مساعد دكتور أستاذ مساعد دكتور أستاذ مساعد دكتور أستاذ مساعد دكتور أستاذ مساعد دكتور
ـ ـ زهير قاسم الخشاب

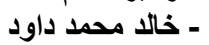
ـ ـ هاشم أحمد سلمان دان ـ ثيلام يونس علاوي

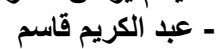
ـ ضر غام جاسم ـ وديع ياسين التكريتي - لؤي الصميدعي - زهير قاسم الخشّاب - محمد خضر أسمر أخماب ـ ـ هاشم أحمد سلمان

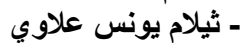
- عبد الكريم قاسم - معتز يونس ذبن النون ـ - ضر غام جاسم عبد الكريم - سبهان محمود الزهيري - سعد فاضل - سمبل 
وطبيعة أرضية الملعب وخصوصية الكرة، إذ قام الباحثان بتصميم مجموعة من الاختبارات لبعض المهارات الأساسية للاعبي خماسي كرة القدم، والجدول رقم (Y) يبين أسماء الاختبارات.

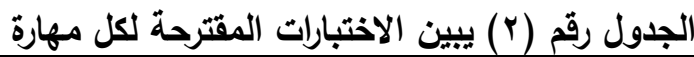

\begin{tabular}{|c|c|c|}
\hline اسم الإختبار & 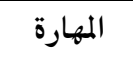 & ت \\
\hline 1. التهديف من الكرات الثابتة. & \multirow{6}{*}{ التهديف } & \multirow{6}{*}{1} \\
\hline r. r. التهديف من الحركة من الكرة القادمة من جانب الرجل المسيطرة. & & \\
\hline لـ. التهديف من الحركة من الكرة القادمة من الخلف. & & \\
\hline ع. التهديف من الكرات الثابتة على ستة تقسيمات. & & \\
\hline مـ التهديف من الحركة على التقسيمات المتداخلة والمرسومة داخل الهدف. & & \\
\hline 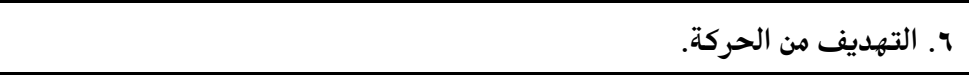 & & \\
\hline 1. الدحرجة بالكرة حول الشواخص الموضوعة على محيط مربع طول ضلعه (ه) أمتار. & \multirow{8}{*}{ 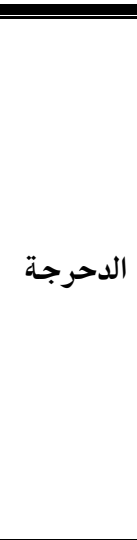 } & \multirow{8}{*}{ r } \\
\hline Y. الدحرجة بالكرة حول (0) شواخص بطريقة بارو. & & \\
\hline r. الدحرجة بالكرة حول (ף) شواخص بأبعاد مختلفة ذهاباً وإياباً. & & \\
\hline ع. الدحرجة بالكرة حول (9) شواخص. & & \\
\hline م. الدحرجة بالكرة حول مثلث متساوي الأضلاع. & & \\
\hline I. الدحرجة بالكرة حول (0) شواخص. & & \\
\hline V V. الدحرجة بالكرة حول (^) شواخص بأبعاد مختلفة ذهاباً وإياباً. & & \\
\hline 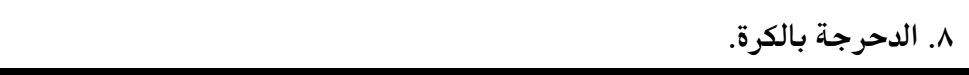 & & \\
\hline 1. تمرير كرة أرضية بالقدم من الدحرجة على مسطبة مقسمة. & \multirow{4}{*}{ التمرير } & \multirow{4}{*}{ r } \\
\hline r. تمرير الكرة بالقدم من الدحرجة ولمدة (·r) ثانية.. & & \\
\hline r. تمرير الكرة بالقدم على الدوائر المتداخلة والمرسومة على الحائط من الكرات الثابتة. & & \\
\hline ع. تمرير الكرة على (£) أهداف. & & \\
\hline
\end{tabular}

: r-

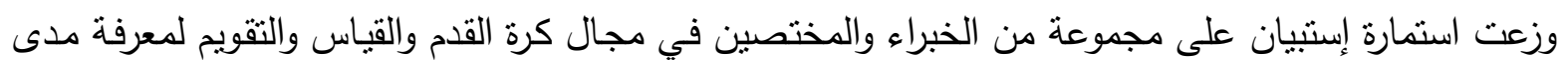

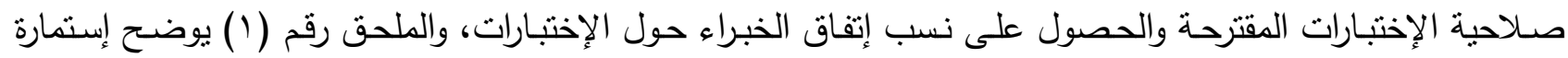
الإستنيان، فيما يبين الجدول رقم (ب) نسب إتفاق السادة الخبراء والمختصين على صلاحية الإختبارات.

* الجدول رقم (r) يبين نسب إتفاق آراء السادة الخبراء والمختصين الإختين

\begin{tabular}{|c|c|c|c|}
\hline نسبة الإتفاق & وحدة قياس & اســـم الإختبــــــار & ت \\
\hline
\end{tabular}

* ملاحظة: قام الباحثان بعرض الإختبارت بكافة تفاصيلها بينما عرضت أسماء الإختبارات في الملقق لضرورات النشر في المجلة. 


\begin{tabular}{|c|c|c|c|}
\hline$(\%)$ & الإختبار & & \\
\hline $1 \cdots$ & 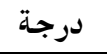 & تمرير الكرة بالقدم من الدحرجة ولمدة (•r) ثانية. & 1 \\
\hline $1 \cdots$ & درجـة & التهديف من الحركة على التقسيمات المتداخلة والمرسومة داخل الهدف. & r \\
\hline $1 \cdots$ & 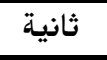 & الدحرجة بالكرة حول (0) شواخص بطريقة بارو. & $r$ \\
\hline ar & 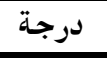 & التهديف من الكرات الثابتة على ستة تقسيمات. & $\varepsilon$ \\
\hline ar & 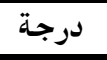 & تمرير الكرة بالقدم على الدوائر المتداخلة والمرسومة على الحائط من الكرات الثابتة. & $\bullet$ \\
\hline$\wedge \varepsilon$ & 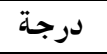 & التهديف من الحركة. & 9 \\
\hline$\wedge \varepsilon$ & 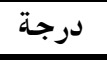 & تمرير كرة أرضية بالقدم من الدحرجة على مسطبة مقسمة. & $\checkmark$ \\
\hline$\wedge \varepsilon$ & 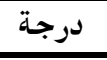 & تمرير الكرة على (ع) أهداف. & $\wedge$ \\
\hline$\sqrt{ }$ & 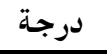 & التهديف من الحركة من الكرة القادمة من الخلف. & 9 \\
\hline$\sqrt{ } 4$ & 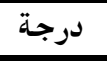 & التهديف من الحركة من الكرة القادمة من جانب الرجل المسيطرة. & $1 \cdot$ \\
\hline$\sqrt{ } 4$ & 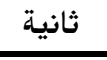 & الدحرجـة بالكرة حول (†) شواخص بأبعاد مختلفة ذهابا وإياباً. & 11 \\
\hline Vq & ثانية & الدحرجـة بالكرة حول (0) شواخص. & ir \\
\hline Vq & ثانية & الدحرجـة بالكرة حول الشواخص الموضوعة على محيط مربع طول ضلعه (0) أمتار. & ir \\
\hline$r \mu$ & ثانية & الدحرجة بالكرة حول مثلث متساوي الأضلاع. & $1 \varepsilon$ \\
\hline 10 & لدرجة & التهديف من الكرات الثابتة. & 10 \\
\hline 10 & ثانية & الدحرجـة بالكرة. & 17 \\
\hline V & 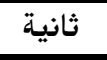 & الدحرجة بالكرة حول (^) شواخص بأبعاد مختلفة ذهابا وإيابا. & IV \\
\hline صفر & ثانية & 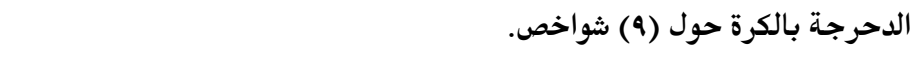 & 11 \\
\hline
\end{tabular}

ويتبين من الجدول رقم (r) انسه تم قبول الإختبارات من تسلسل (ا- با ) لحصولها على نسبة أعلى مـن

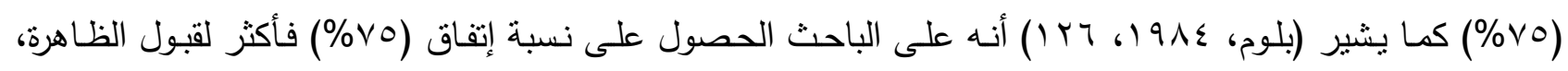
وتستبعد الإختبارات من تسلسل(ء ( - ^ 1 ) لعدم حصولها على نسب إتفاق مقبولة، وبذللك يكون عدد الإختبارات النهائي

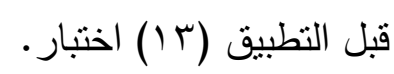
: ب- - ب الإجراءات الإدارية قام الباحثنان ببعض الإجراءات والتسهيلات الإداريـة التي شملت الكتب الرسمية لتسهيل مهمة الباحثان في

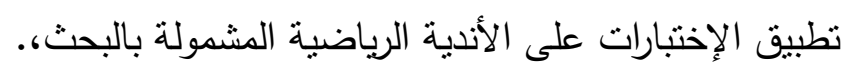

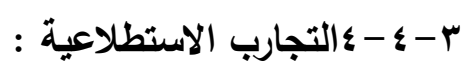

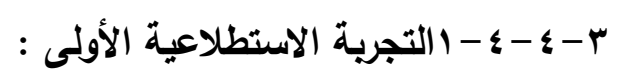

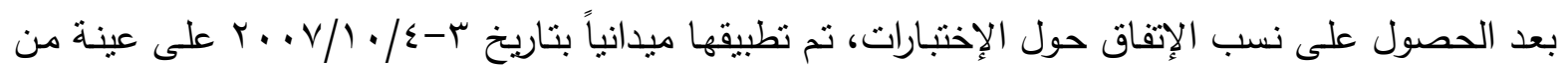

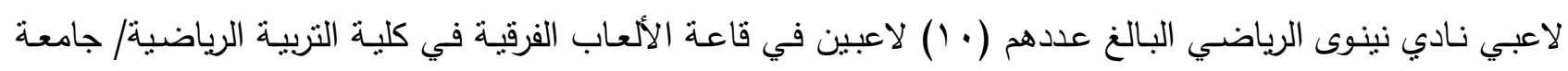
الموصل، وذلك للتعرف على صـلاحية الإختبار من حيث التطبيق وصـلاحية الأجهزة والأدوات وزمن كل اختبار ،ومن خلال التجربة الإستطلاعية الأولى تم إستبعاد إختبار (تمربر الكرة بالقدمين على ع أهداف) وذلك لصعوبة تطبيقه من

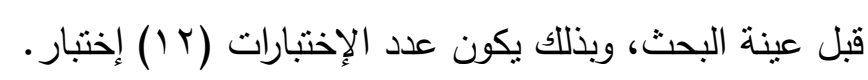
r-

بعد تحديد زمن كل إختبار قسمت الاختبارات على مدار يومين بما يتلاءم وطبيعة أداء الإختبارات، والجدول رقم (ع) يبين تسلسل تطبيق الإختبارات وتوزيعها على مدار يومين وحسب آراء الخبراء. الجدول رقم ( ) (بيين تسلسل تطبيق الإختبارات وتوزيعها على مدار يومين ودين 


\begin{tabular}{|c|c|c|c|c|c|}
\hline \multicolumn{3}{|c|}{ اختبارات اليوم الثاني الثي } & \multicolumn{3}{|c|}{ اختبارات اليوم الأول } \\
\hline 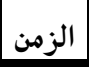 & اسم الإختبار & ت & 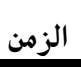 & اسم الاختبار & $ت$ \\
\hline ثانية & التهـف التهديف مسن الحركـة على التقـسيمات المتداخلــة والمرسـومة داخـل & 1 & 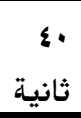 & التهديف بالقدم من الكرات الثابتة على الأرض & 1 \\
\hline $\begin{array}{r}\text { ثانية } \\
\text { •l }\end{array}$ & الدحرجة بالكرة حول (ه) شواخص بطريقة بارو & r & ثانية & مختلفة ذهاباً وإياباً & r \\
\hline ثانية & التهديف من الحركة من الكرة القادمة من الخلف & $r$ & 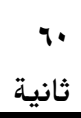 & التهديف من الحركة من الكرة القادمة من جانسب & $r$ \\
\hline $\begin{array}{r}\text { ro } \\
\text { ثانية }\end{array}$ & تمرير الكرة على الدوائر المتداخلة المرسومة على الحسائط مـن الكرات & $\varepsilon$ & ثانية & التهديف من الحركة & $\varepsilon$ \\
\hline 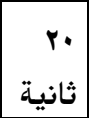 & الدحرجة بالكرة حسول الـشواخص الموضسوعة على محسيط مربـع طـول & 。 & 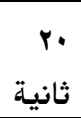 & الدحرجة بالكرة حول (ه) شواخص & 。 \\
\hline 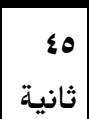 & تمرير كرة أرضية من الدحرجة على مسطبة مقسمة & 9 & 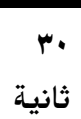 & ثانية & 9 \\
\hline
\end{tabular}

ب

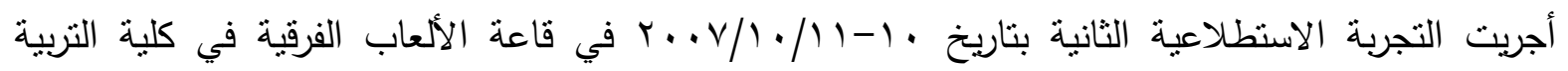

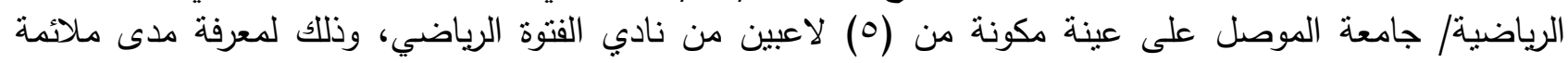

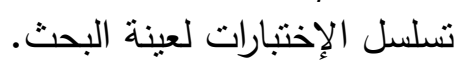
r-

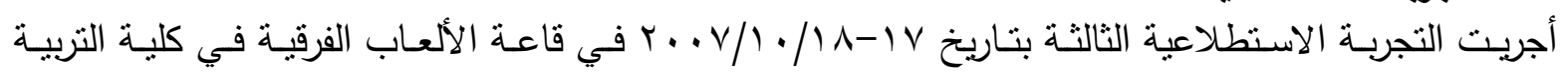

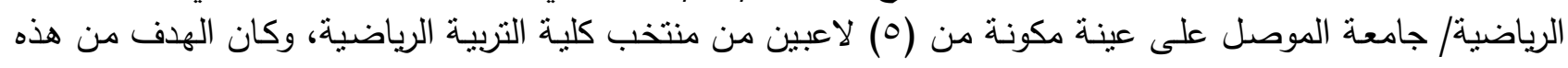

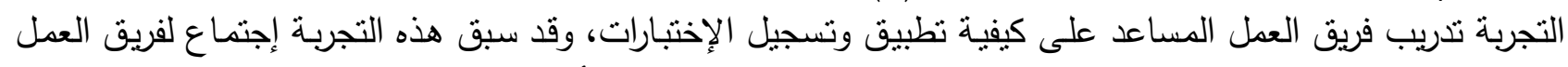

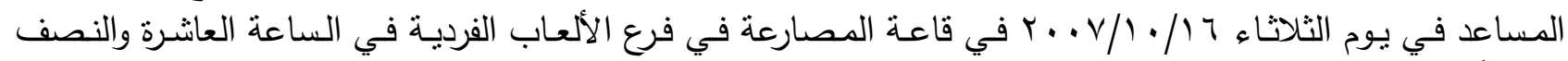

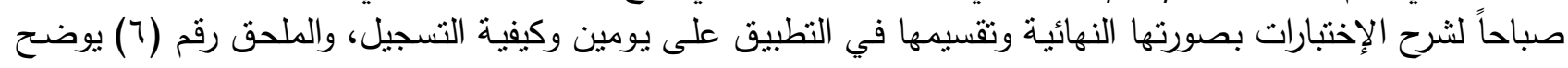

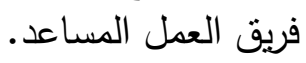

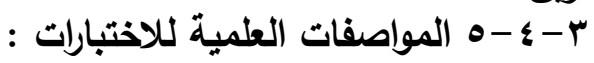
: ب "يعرف الثبات بأنه: درجة الاتساق أو التجانس بين نتائج مقياسين في تقدير صفة أو سلوك ما أو قدرة الاختبار

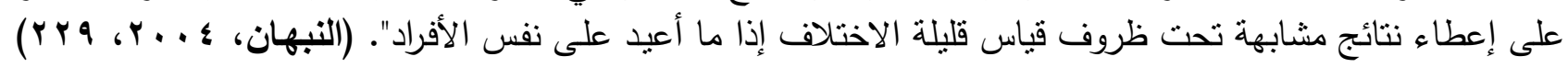

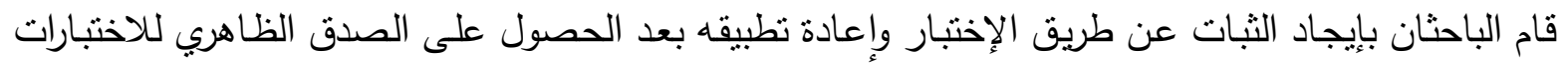

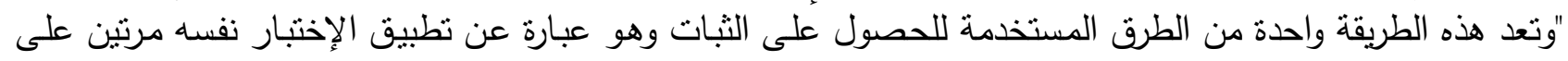

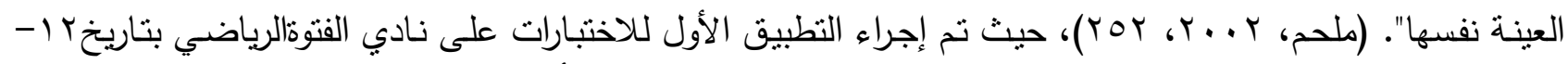

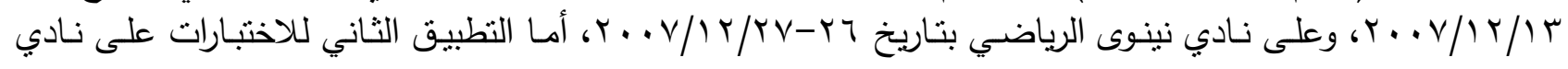

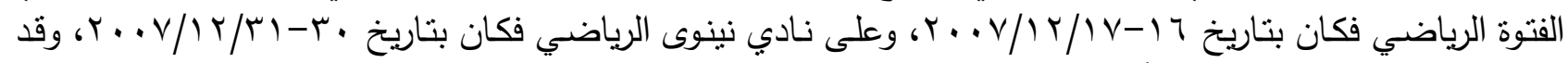

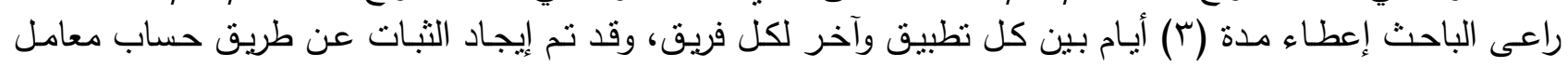

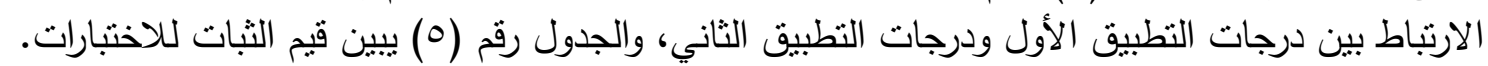
الجدول رقم (•) يبين المعاملات العلمية للإختبارات

\begin{tabular}{|c|c|c|c|}
\hline الصدق الذات & الثبات & اســــم الاختبار & $ت$ \\
\hline • ד & $\cdot, \mathrm{V} \varepsilon$ & تمرير الكرة بالقدم من الدحرجة ولمدة (·r) ثانية. & 1 \\
\hline
\end{tabular}




\begin{tabular}{|c|c|c|c|}
\hline$\cdot, \wedge \varepsilon$ & $\cdot, \mathrm{Vr}$ & التهديف من الحركة على التقسيمات المتداخلة والمرسومة داخل الهدف. & r \\
\hline$\cdot 9$ & $\cdot, \wedge \Lambda$ & الدحرجة بالكرة حول (0) شواخص بطريقة بارو. & $r$ \\
\hline$\cdot, \mathrm{AV}$ & $\cdot, \mathrm{VV}$ & التهديف من الكرات الثابتة على ستة تقسيمات. & $\varepsilon$ \\
\hline$\cdot, \wedge$ & $\cdot, \mathrm{V}$ & تمرير الكرة بالقدم على الدوائر المتداخلة والمرسومة على الحائط من الكرات الثابتة. & 0 \\
\hline$\cdot, \mathrm{AV}$ & $\cdot, \mathrm{VV}$ & التهديف من الحركة. & 9 \\
\hline$\cdot, \wedge$ † & $\cdot, \mathrm{V} \varepsilon$ & تمرير كرة أرضية بالقدم من الدحرجة على مسطبة مقسمة. & $v$ \\
\hline$\cdot, \Lambda$ & $\cdot, \mathrm{V \Lambda}$ & التهديف من الحركة من الكرة القادمة من الخلف. & $\Lambda$ \\
\hline$\cdot, \wedge \uparrow$ & $\cdot, \mathrm{V} \varepsilon$ & التهديف من الحركة من الكرة القادمة من جانب الرجل المسيطرة. & 9 \\
\hline$\cdot, \wedge \varepsilon$ & $\cdot, \mathrm{VY}$ & الدحرجة بالكرة حول (ף) شواخص بأبعاد مختلفة ذهاباً وإياباً. & 1. \\
\hline$\cdot, \mathrm{TV}$ & $\cdot, \S$ & الدحرجة بالكرة حول (0) شواخص. & 11 \\
\hline$\cdot, \mathrm{v} \cdot$ & $\cdot, \bullet$ & الدحرجة بالكرة حول الشواخص الموضوعة على محيط مربع طول ضلعه (0) أمتار. & ir \\
\hline
\end{tabular}

من الجدول(0) يتبين ان الاختبارات من تسلسل (1- • (1) حصلت على معامل ثبات عالي اذ اعتمد الباحثان

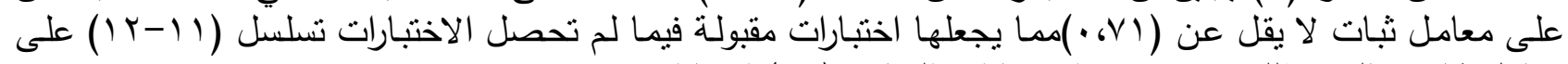

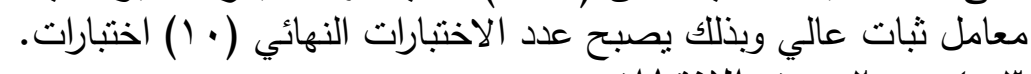
: r-

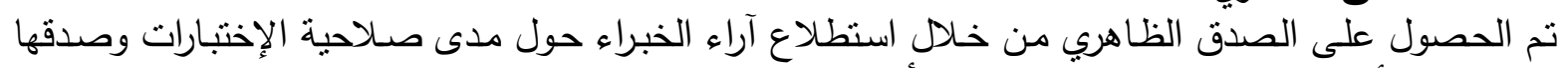

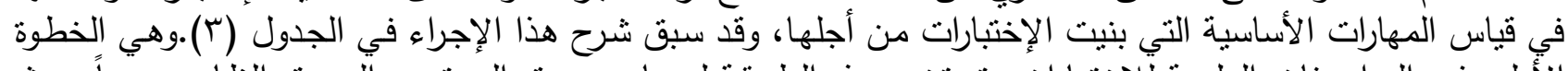

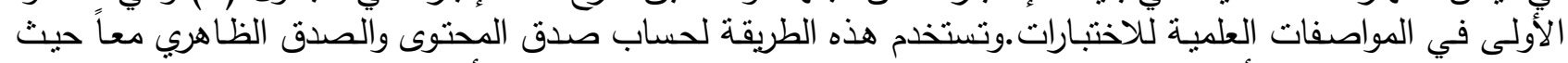

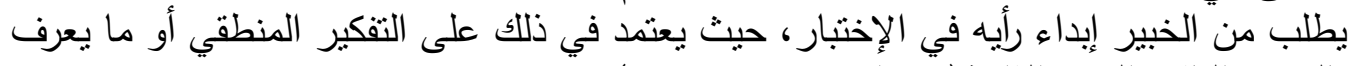

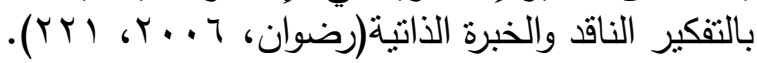

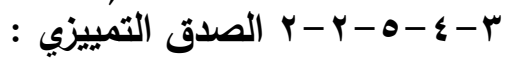

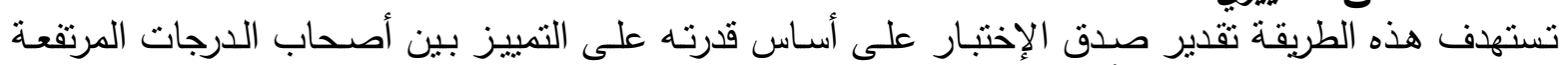

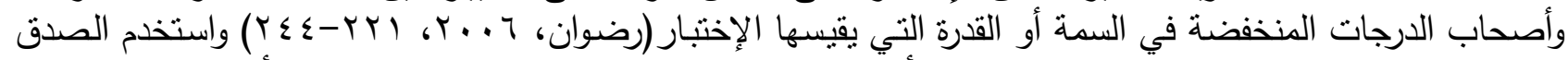

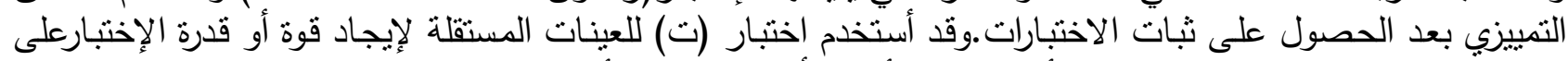

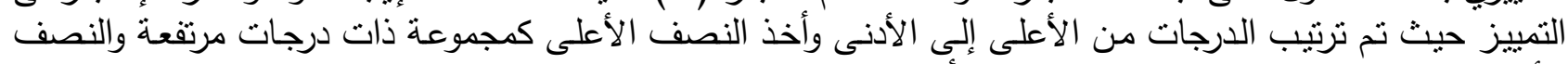

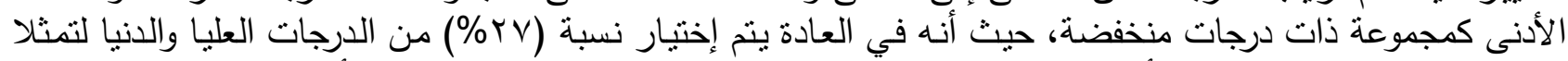

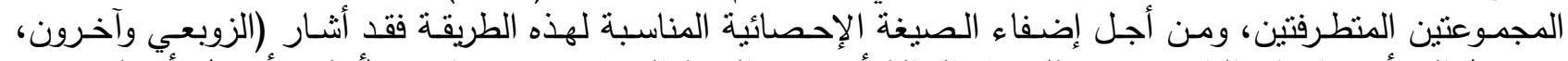

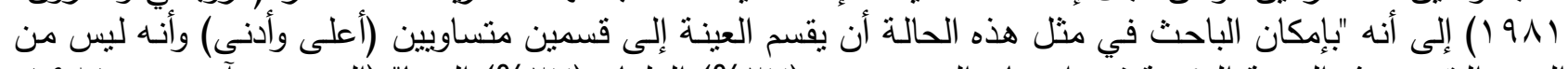

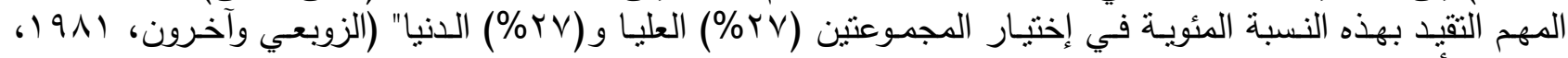

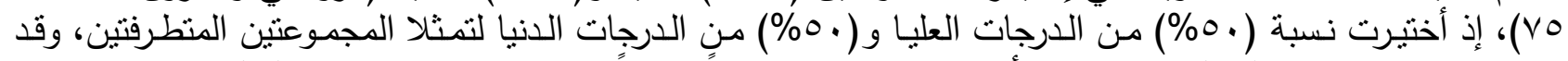

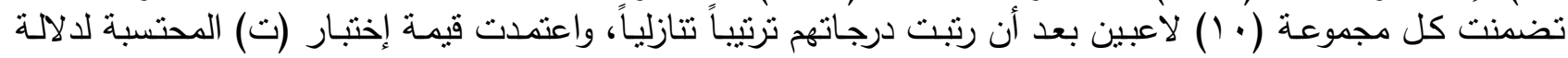

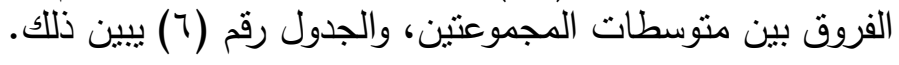

الجدول رقم (؟) قيمة (ت) المحسوية بين المجموعات المتطرفة

\begin{tabular}{|c|c|c|c|c|c|}
\hline قالمحسو (ت) & اسم الإختبار & ت & |المحسمة (ت) & اسم الإختبار & ت \\
\hline ?.r. & والداباًٍ الدجة بـالكرة حـول (ף) شـواخص بأبعـاد مختلفـة ذهابـاً & 7 & 9,47 & تمرير الكرة بالقدم من الدحرجة ولمدة (•r) ثانية & 1 \\
\hline
\end{tabular}




\begin{tabular}{|c|c|c|c|c|c|}
\hline $\mathrm{V}, \mathrm{VYY}$ & تمرير كرة أرضية بالقدم من الدحرجة على مسطبة مقسمة. & $v$ & " & التهديف من الحركة. & r \\
\hline${ }^{\circ} \varepsilon$, rav & تمريـر الكـرة بالقـدم علـى الـدوائر المتداخلــة والمرسومة علـى & $\wedge$ & $\circ, 11 r$ & التهديف من الحركة من الكرة القادمة من جانب & $r$ \\
\hline${ }^{\circ} \varepsilon, \wedge \varepsilon ฯ$ & التهديف من الكرات الثابتة على ستة تقسيمات. & 9 & $7, \S 1$. & التهديف من الحركة من الكرة القادمة من الخلف. & $\varepsilon$ \\
\hline $0,9 \leqslant 1$ & داخل الهـدفيف مسن الحركـة علـى التقـسيمات المتداخلــة والمرسومة & 1. & $\circ, \mathrm{TVV}$ & الدحرجة بالكرة حول (0) شواخص بطريقة بارو. & ○ \\
\hline
\end{tabular}

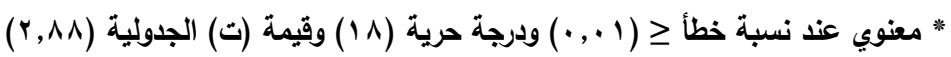

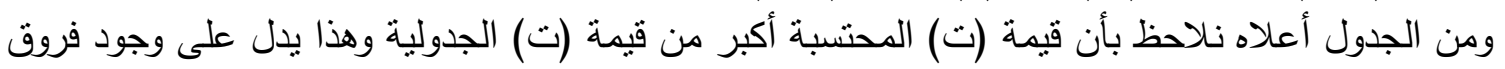

معنوية تدلل على قدرة الإختبارات في التمييز بين المستوبات. r- r-

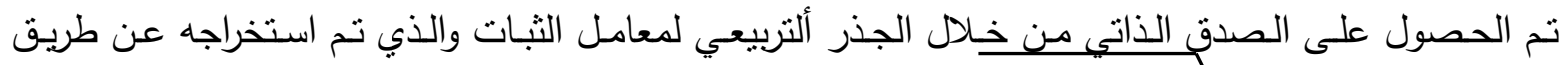

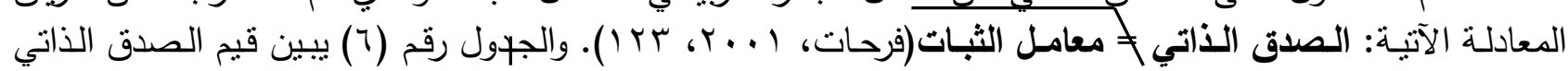
للاختبارات.

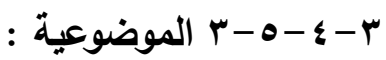

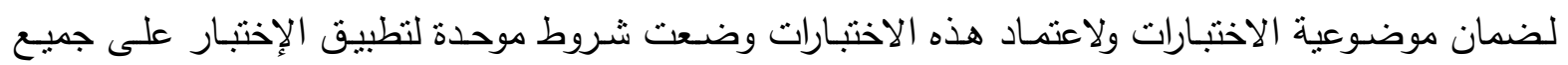

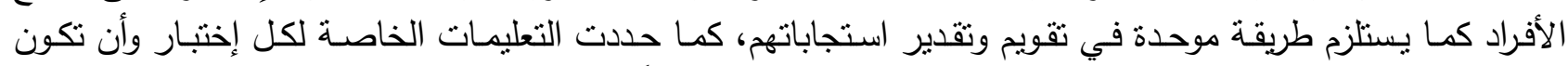

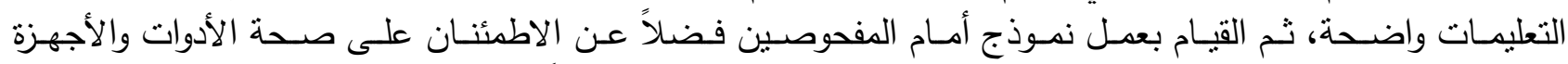

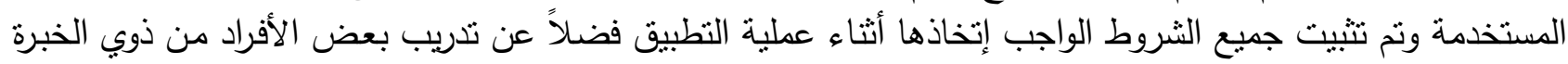

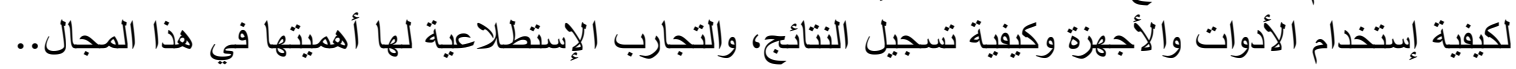

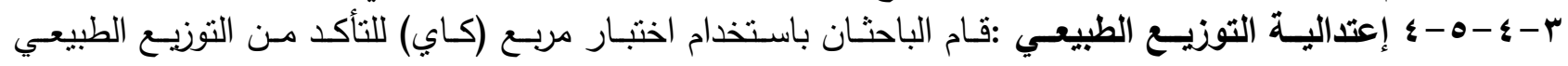

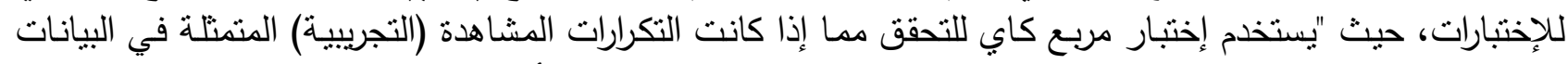

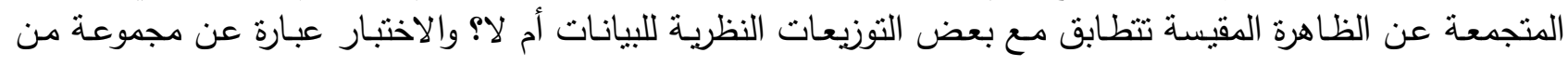

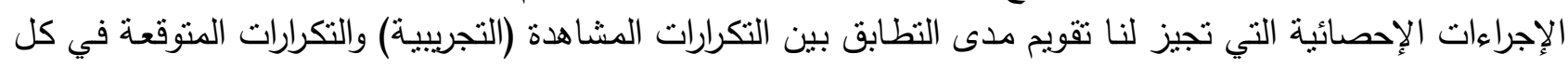

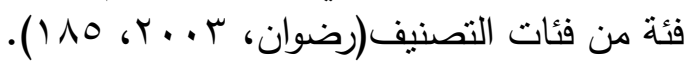
الجدول رقم (V) يبين قيمة اختبار مربع كاي لكل الإختبارات

\begin{tabular}{|c|c|c|}
\hline كان & اســـم الاختبار & ت \\
\hline $0, \Lambda \cdot \mu$ & تمرير الكرة بالقدم من الدحرجة ولمدة (•ץ) ثانية & 1 \\
\hline$Y,\{\Lambda \Lambda$ & التهديف من الحركة على التقسيمات المتداخلة والمرسومة داخل الهدف. & r \\
\hline$\Upsilon, \mathrm{AVV}$ & 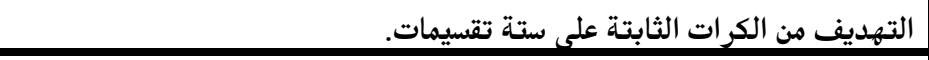 & $r$ \\
\hline r,orA & التهديف من الحركة. & $\varepsilon$ \\
\hline Y, $9 \varepsilon Y$ & التهديف من الحركة من الكرة القادمة من جانب الرجل المسيطرة. & $\bullet$ \\
\hline 0,919 & التهديف من الحركة من الكرة القادمة من الخلف. & 9 \\
\hline צ & الدحرجة بالكرة حول (0) شواخص بطريقة بارو. & $\mathrm{v}$ \\
\hline V,VIT & الدحرجة بالكرة حول (ף) شواخص بأبعاد مختلفة ذهاباً وإياباً. & $\Lambda$ \\
\hline$\Lambda$, Var & تمرير كرة أرضية بالقدم من الدحرجة على مسطبة مقسمة. & 9 \\
\hline $9,1 \leqslant r$ & تمرير الكرة بالقدم على الدوائر المتداخلة والمرسومة على الحائط من الكرات الثابتة. & 1. \\
\hline
\end{tabular}

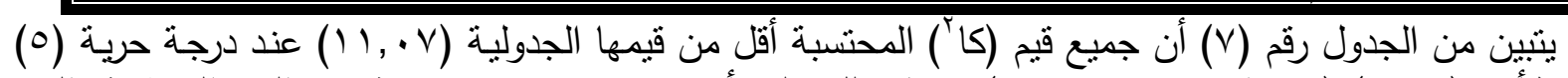

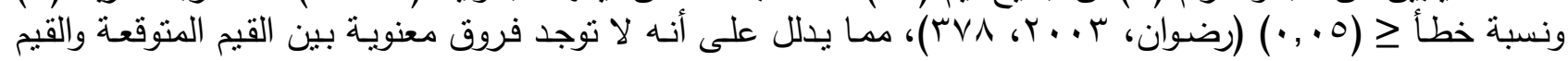

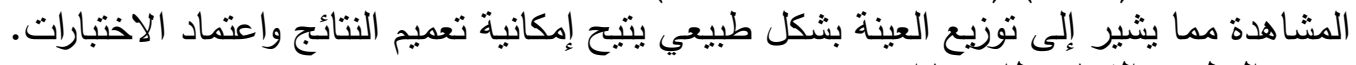
r-

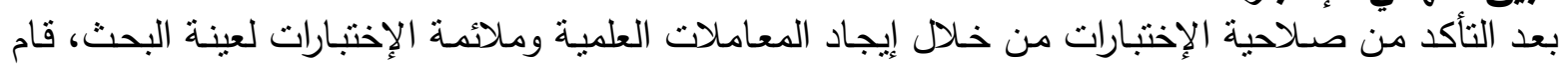

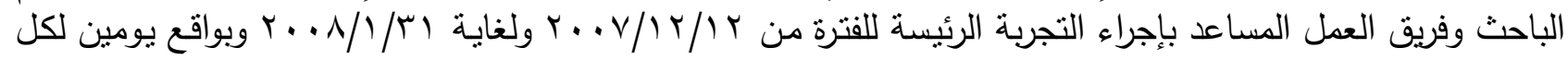


نادي مراعياً بذلك توزيع الإختبارات على يومين وفقاً للتسلسل المنطقي للإختبارات، وكذلك إجراء الإختبارات في الساعة الثانية بعد الظهر لكل أندية البحث، والإن الجدول رقم (^) يبين ذلك.

الجدول رقم (^) يبين تسلسل تطبيق الإختبارات وتوزيعها على مدار يومين

\begin{tabular}{|c|c|c|c|c|c|}
\hline \multicolumn{3}{|c|}{ إختبارات اليوم الثاني } & \multicolumn{3}{|c|}{ إختبارات اليوم الأول } \\
\hline | - الإختبار & اسم الإختبار & ت & الإختبار & اسم الإختبار & ت \\
\hline 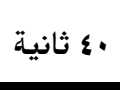 & الهدف التهـيف مـن الحركسة علـى التقـسيمات المتداخلـة والمرسـومة داخـل & 1 & 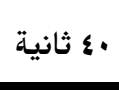 & التهديف من الكرات الثابتة على ستة تقسيمات & 1 \\
\hline 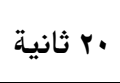 & الدحرجة بالكرة حول (0) شواخص بطريقة بارو & r & 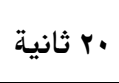 & والدحرِجة بالكرة حول (ף) شواخص بأبعاد مختلفة ذهابـا & r \\
\hline 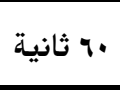 & التهديف من الحركة من الكرة القادمة من الخلف & $\mu$ & 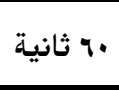 & المسيطرة التهديف من الحركة من الكرة القادمة مسن جانسب الرجـل & $r$ \\
\hline 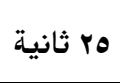 & تمرير الكرة على الدوائر المتداخلة المرسومة على الحــائط مـن الكـرات & $\varepsilon$ & 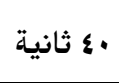 & التهديف من الحركة & $\varepsilon$ \\
\hline 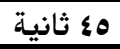 & تمرير كرة أرضية من الدحرجة على مسطبة مقسمة & 0 & 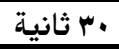 & تمرير الكرة بالقدم من الدحرجة ولمدة (•r) ثانية & 0 \\
\hline
\end{tabular}

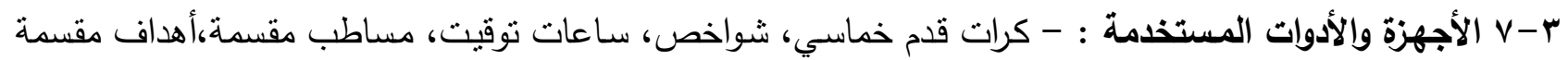
مرسومة على قماش، أشرطة قياس، صافرات، أشرطة لاصقة ملونة.

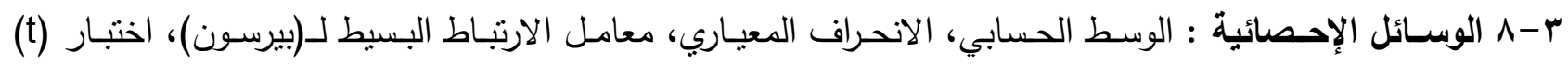

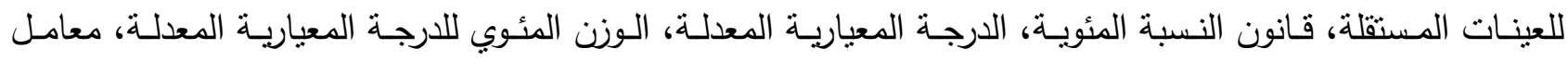

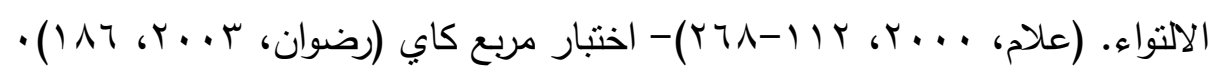

ع -عرض النتائج :سبتتاول الباحثان في هذا الباب وصف كل إختبار من الإختبارات التي طبقت على عينـة البحث فضلاً عن الدرجات والمستويات المعيارية لكل إختبار وهي:

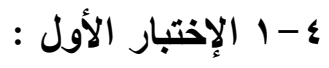

- اسم الإختبار: تمرير الكرة بالقدم من الاحرجة لمدة ( • ب) ثانية. - الهذف من الاختبار: قياس سرعة ودقة تمرير الكرة بالقدم من الاحرجة لمدة ( • ب) ثانية للاعبي خماسي كرة القدم. - الأدوات المستخدمة: (r) كرات خماسي، ساعة نوقيت، حائط أو مسطبة. - طريقـة الأداء: عند سماع إثـارة البدء يقوم المختبر بدحرجـة الكرة حول الشاخص ويعود ليمررهـا من خلف الخط المرسوم إلى الأهداف المرسومة، وكما هو موضح في الثكل رقم (1) على الحائط أو المسطبة من على بعد (0) أمتار

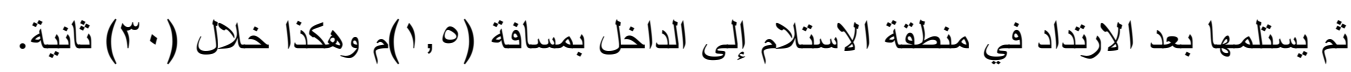
- شروط الاختبار: * *جب أن تكون التمريرة أرضية. * يجب أن يبدأ المختبر عند سماع إنثارة البدء. * يحق للمختبر إستام الكرة المرتدة من الحائط أو المسطبة بعد تمريرها إلى الداخل من خط البداية بمسافة (0, (1)م.

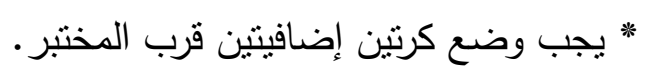
* إذا ارتدت الكرة خارج منطقة أل (0, (1)م للجانبين يعطى المختبر كرة إضافية (احتياط) من القائم بالاختبار . * للمختبر الحرية في إستخدام أي من القدمين في عملية الدحرجة والتمرير وفي أي جزء من القدم. 


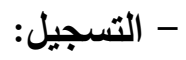

* يمنح المختبر (Y) درجة إذا لمست الكرة المستطيل في الوسط. * يمنح المختبر (1) درجة إذا لمست الكرة المستطيلين الجانبيين.

* يمنح المختبر (صفر) أذا خرجت الكرة خارج المستطيلات. * يمنح المختبر الدرجة الأكبر إذا لمست الكرة الخط بين التقسيمات. * تحسب الدرجة من جمع درجات الدقة خلال أل ( • ب) ثانية. - عدد المحاولات: للمختبر محاولتان تحتسب المحاولة الأفضل.

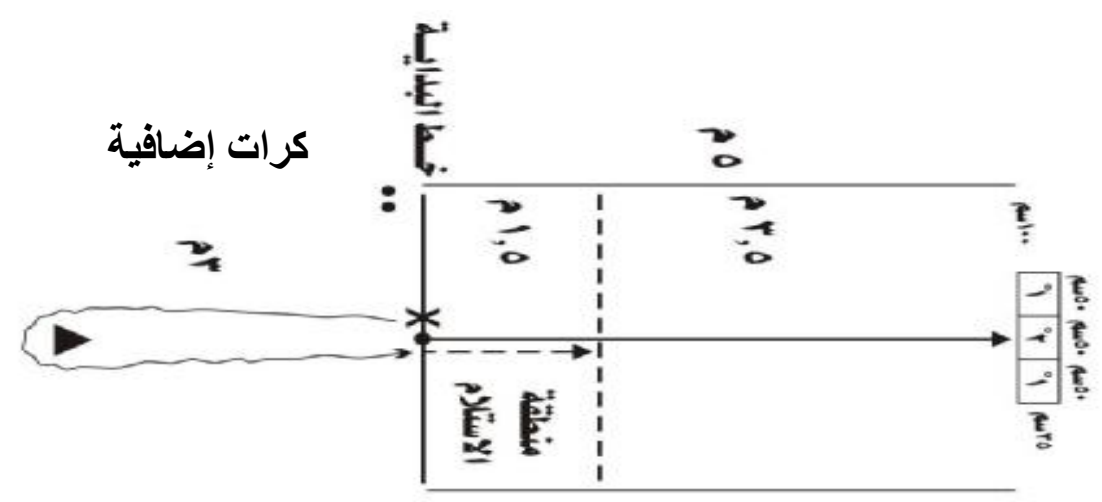

خط استلام الكرة خط تمرير الكرة

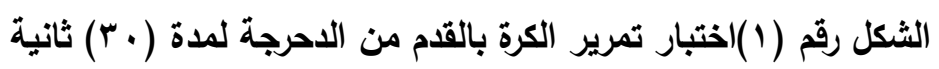

الوصف الإحصائي لإختبار : تمريز الكرة بالقدم من الاحرجة لمدة ( • ب) ثانية.

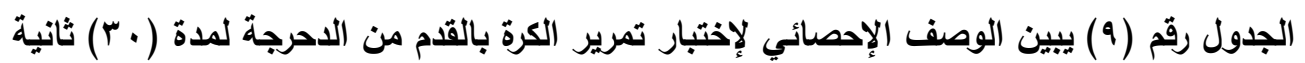

\begin{tabular}{|c|c|c|c|c|}
\hline كا' & الإلتواء & المنوال & $\varepsilon \pm$ & س \\
\hline$\bullet, \Lambda \cdot r$ & $\cdot, \wedge$ & 1. & $1, \mu v$ & $1 \cdot, 1 r$ \\
\hline
\end{tabular}

مـن خـلال الجدول رقم (9) نستـل أن: الإختبار ملائم لمستوى العينة، ويقترب مـن التوزيع الطبيعي بدلالـة

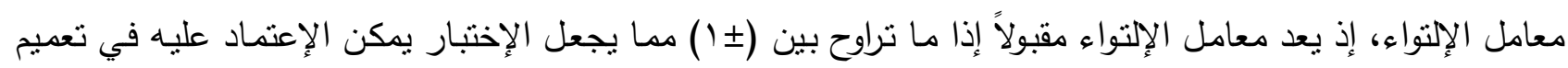

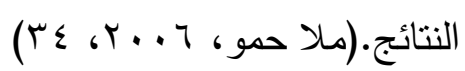

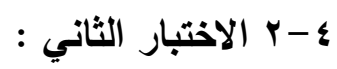

- اسم الإختبار: التهايف من الحركة على التقبيمات المتداخلة والمرسومة داخل الهدف. - الهـدف مـن الاختبـار : قياس دقـة التهديف مـن الحركة على التقسيمات المتداخلـة والمرسومة داخل الهدف للاعبي خماسي كرة القدم. - الأدوات المستخدمة: ( • () كرات خاصة بخماسي كرة القدم، هدف خاص بخماسي كرة القدم.

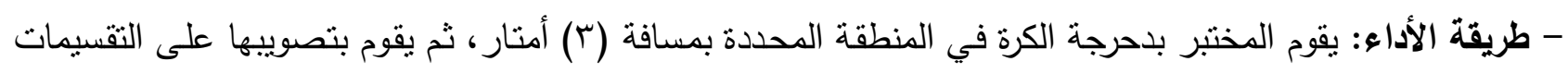
المرسومة على الهدف والتي أبعادها كما في الشكل رقم (Y) من على بعد (• (1) أمتار ثم العودة إلى الكرة الثانيـة والدحرجة بها وتصوييها بنفس الطريقة وهكذا، يقوم المختبر بتصويب ( • () كرات. - شروط الاختبار: * يجب أن يكون التهديف من داخل منطقة الاحرجة. 
* للمختبر الحرية في إستخدام أي من القدمين في التهديف وفي أي جزء من القدم. * للمختبر الحرية بإستخدام مختلف الطرق الفنية في عملية الدحرجة وبكلتا القدمين.

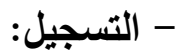
* يمنح المختبر (1) درجة إذا لمست الكرة التقسيم الأول في الوسط، أو لمست الكرة عارضة أو عمودي الهدف. * يمنح المختبر (r) درجة إذا لمست الكرة التقسيم الثاني. * بمنح المختبر (r) درجة إذا لمست الكرة التقسيم الثالث. * بمنح المختبر (ع) درجة إذا لمست الكرة التقسيم الرابع. * يمنح المختبر (صفر) إذا لم تلمس الكرة أي من التقسيمات، أو قام المختبر بتصويب الكرة من خارج منطقة الدحرجة، إلى أو كانت الكرة متلحرجة على الأرض أثناء التهديف. * يمنح المختبر الدرجة الأكبر إذا لمست الكرة الخط بين تقسيمات الهدف. * الدرجة الكلية للاختبار هي ( • ع درجة.

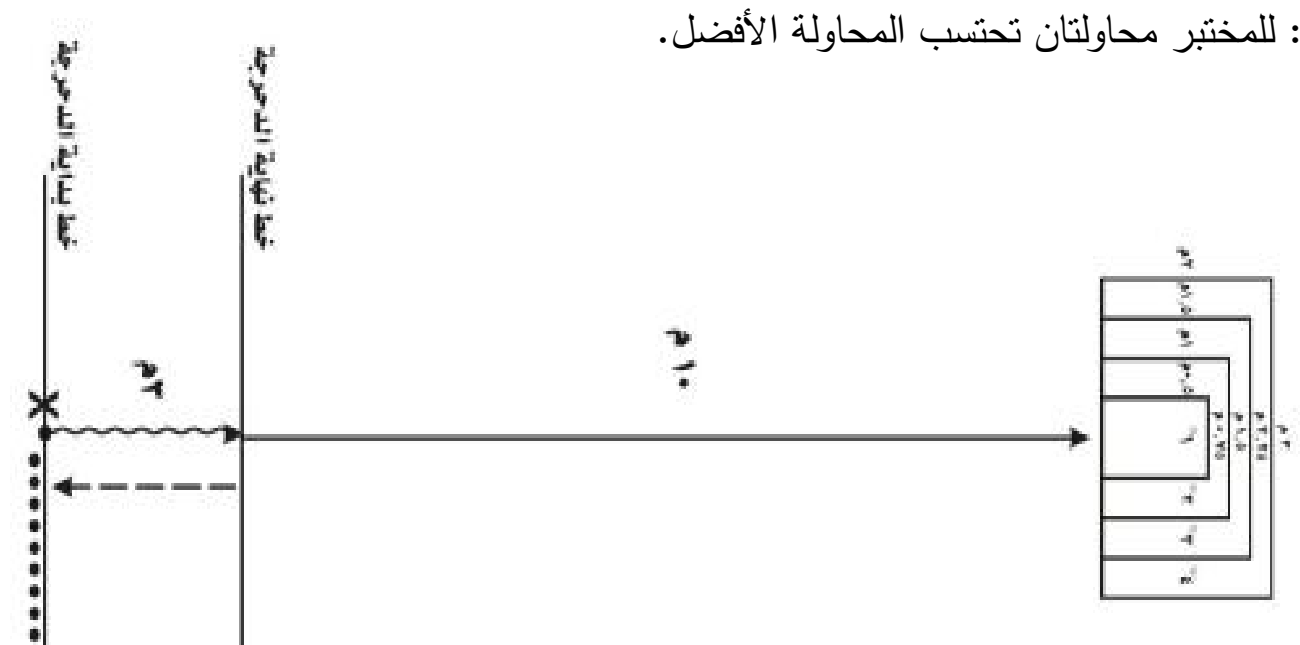

الثكل رقم (Y)(ختبار التهديف من الحركة على التقسيمات المتداخلة والمرسومة داخل الهذف الوصف الإحصائي لإختبار: التهايف من الحركة على التقسيمات المتداخلة والمرسومة داخل التهل الهذف.

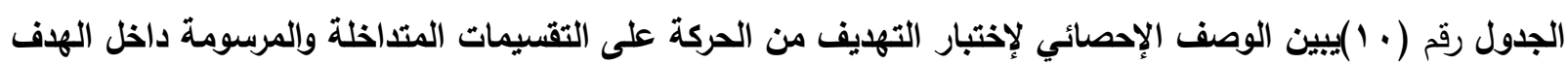

\begin{tabular}{|c|c|c|c|c|}
\hline Sا & الإلتواء & المنوال & $\varepsilon \pm$ & س \\
\hline$\curlyvee, \varepsilon \wedge \wedge$ & • & $r \varepsilon$ & $\varepsilon, r$. & $r \bullet, r q$ \\
\hline
\end{tabular}

من خلال الجدول رقم (• () نستدل أن: الإختبار ملائم لمستوى العينة، ويقترب من التوزيع الطبيعي مما يجعله اختبارا يمكن الإعتماد عليه في تعميم النتائج.

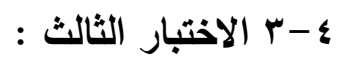

- اسم الإختبار : التهايف من الكرات الثابتة على ستة تقسيمات. - الهذف من الاختبار: قياس دقة التهديف من الكرات الثابتة على ستة تقسيمات للاعبي خماسي كرة القدم. - الأدوات المستخدمة: كرات خاصة بخماسي كرة القدم، هدف خماسي كرة القدم. 


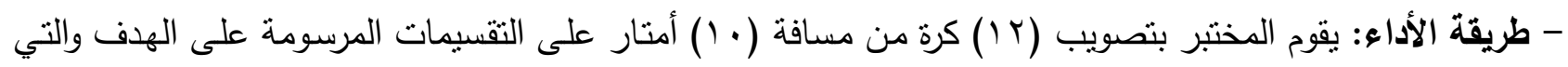

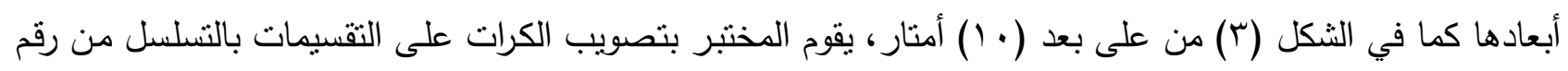

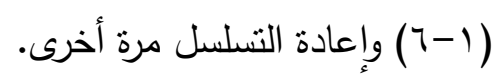

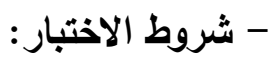

" *جب أن يكون التهديف من على خط البداية. * للمختبر الحرية في إستخدام أبي من القدمين في التهديف وفي أي جزء من القدم.

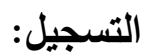

" مينح المختبر ( ) درجة إذا لمست الكرة التقسيم المطلوب أو خطوطه.

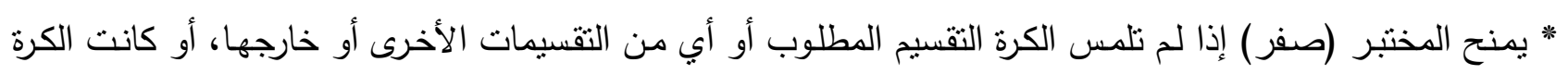
متدحرجة على الأرض أثناء عملية التهديف.

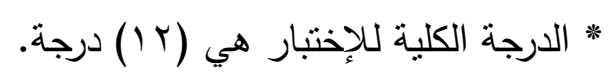
- عدد المحاولات: للمختبر محاولتان تحتسب المحاولة الأفضل.

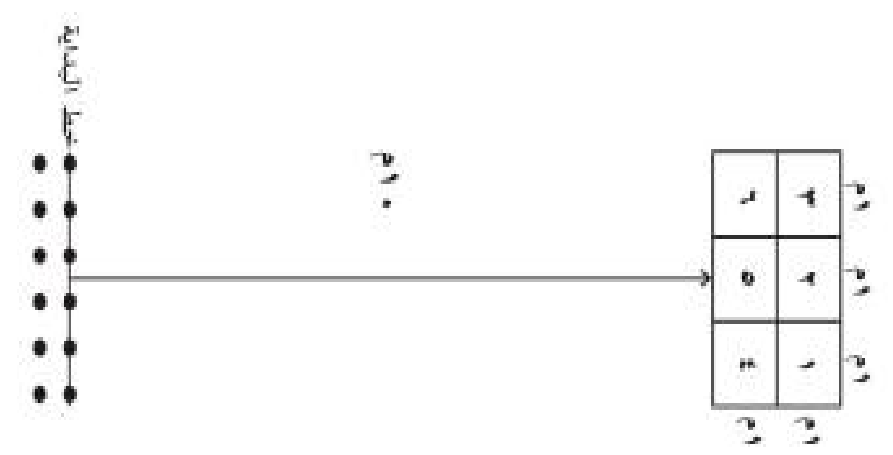

الثكل رقم (ץ) إختبار التهايف من الكرات الثابتة على ستّة تقسيمات

الوصف الإحصائي لإختبار: التهايف من الكرات الثابتة على ستة تقسيمات.

الجدول رقم (1) ايبين الوصف الإحصائي لإختبار التهديف من الكرات الثابتة على ستة تقسيمات

\begin{tabular}{|c|c|c|c|c|}
\hline كاי & الإلتواء & المنوال & $\varepsilon^{ \pm}$ & س \\
\hline$\checkmark, A \vee V$ & ., & $\wedge$ & $1, V Y$ & $v, 10$ \\
\hline
\end{tabular}

من خلال الجدول رقم (1') نستنل أن: الإختبار ملائم لمستوى العينة، ويقترب من التوزيع الطبيعي مما يجعله إختباراً يمكن الاعتماد عليه في تعميم النتائج.

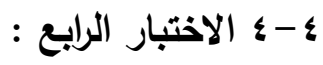

- اسم الإختبار: التهويف من الحركة. - الهدف من الاختبار: قياس دقة التهديف من الحركة للاعبي خماسي كرة القدم.

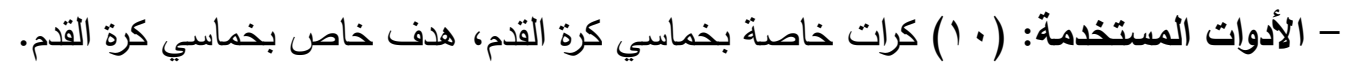

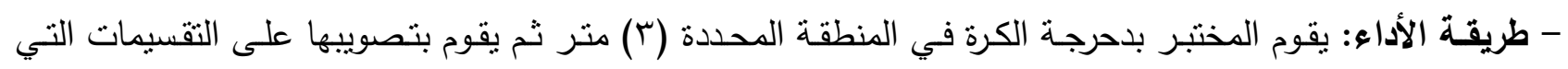

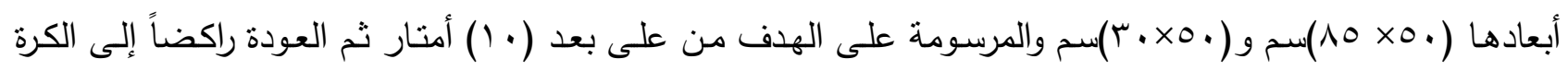




\section{تصميم وبناء اختبارات لقياس بعض المهارات الأساسية للاعبي أندية الدوري الممتاز العراقي ....}

الثانية والدحرجة بها وتصويبها على الهدف بنفس الطريقة وهكذا، يقوم المختبر بتهديف ( • () كرات، وكما هو موضح

في الثكل (飞).

- شروط الاختبار: * يجب أن يكون التهديف من داخل منطقة الاحرجة. * للمختبر الحرية بإستخدام مختلف الطرق الفنية في عملية الدحرجة وبكلتا القدمين. * للمختبر الحرية في إستخدام أي من القدمين في التهديف وفي أي جزء من القدم. - التسجيل: * يمنح المختبر (0) درجة إذا لمست الكرة التقسيمات في الزوايا العليا للهدف. * يمنح المختبر (ع) درجة إذا لمست الكرة التقسيمات في الزوايا السفلى للهدف. * يمنح المختبر (r) درجة إذا لمست الكرة التقسيمات في الزوايا العليا أو السفلى للاخل. * يمنح المختبر (Y) درجة إذا لمست الكرة التقسيمات في الزوايا الوسطية على جانبي الهدف. * يمنح المختبر (1) درجة إذا لمست الكرة منتصف الهدف، أو لمست الكرة عارضة أو عمودي الهدف. * يمنح المختبر (صفر) إذا لم تلمس الكرة أي من تقسيمات اليدف، أو قاد المختنر لتصوبـ الكرة مـان خار جـ منطقة

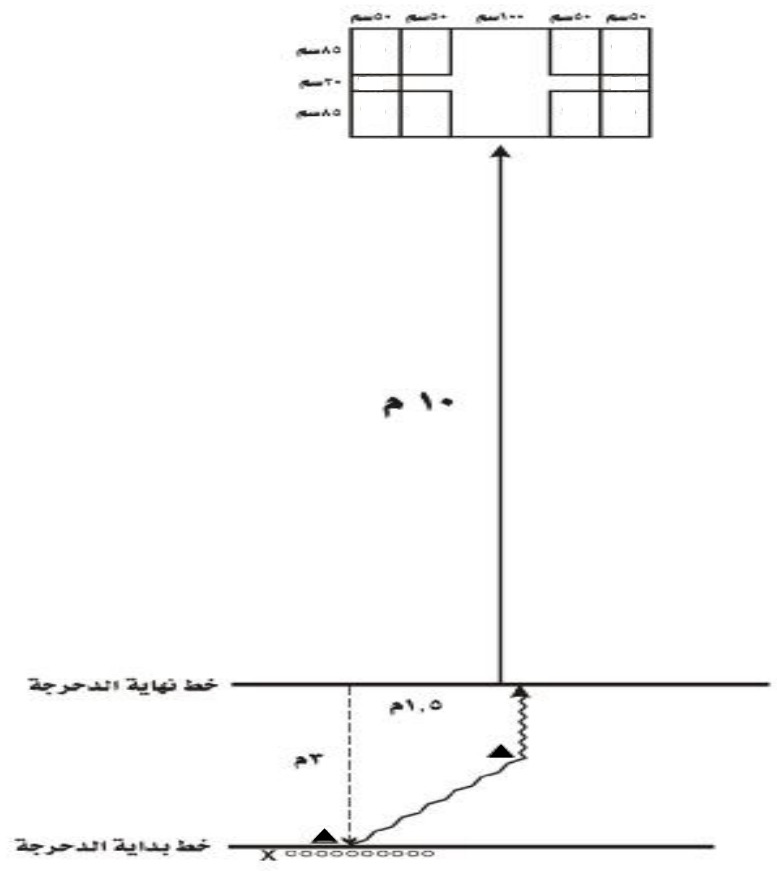

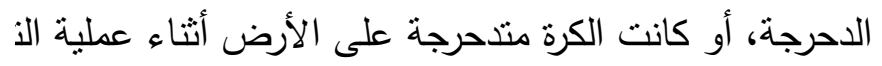

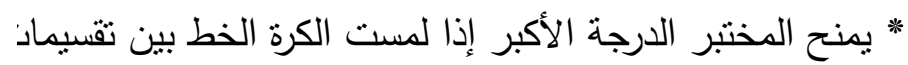
* الدرجة الكلية للإختبار هي ( •.0) درجة. - عدد المحاولات: للمختبر محاولتان تحتسب المحاولة الأ الثكل رقم (؛) إختبار التهديف من الحركة الوصف الإحصائي لإختبار : التهريف من الحركة.

\begin{tabular}{|c|c|c|c|c|}
\hline كا'r & الإلتواء & المنوال & $\varepsilon^{ \pm}$ & س \\
\hline Y,OYA & $\cdot, r r$ & ro & \&,Or & rq, \\
\hline
\end{tabular}

من خـلال الجدول (r (1) نستدل أن: الإختبـار ملائم لمستوى العينة، ويقترب من التوزيـع الطبيعي ممـا يجعله إختباراً يمكن الإعتماد عليه في تعميم النتائج.

ع - ع الاختبار الخامس :

- اسم الإختبار: التهديف من الحركة من الكرة القادمة من جانب الرجل المسيطرة. 
- الهدف من الاختبار: قياس دقة التهديف من الحركة من الكرة القادمة من جانب الرجل المسيطرة للاعبي خماسي كرة القدم.

- الأدوات المستخدمة: (• (1) كرات خاصة بخماسي كرة القدم، هدف خاص بخماسي كرة القدم.

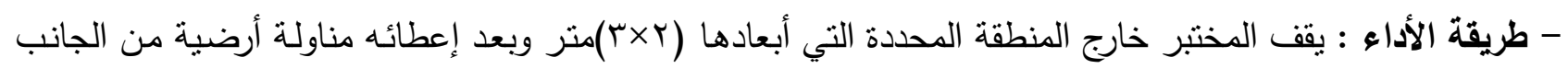

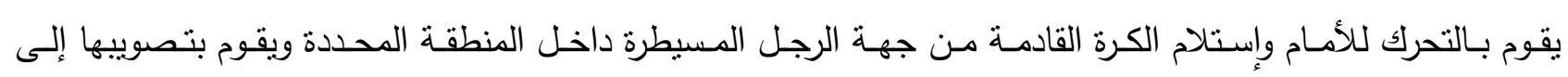

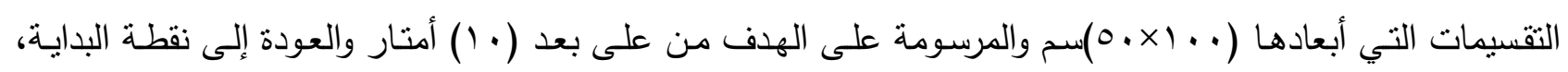

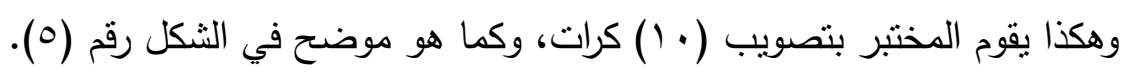

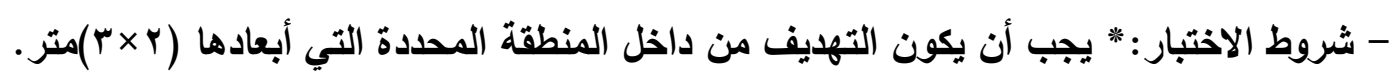

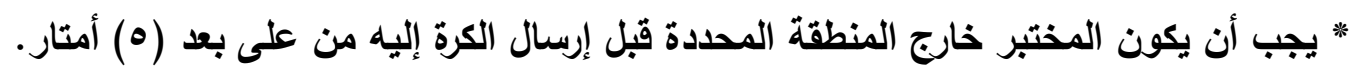
* تمرر للمختبر كرة أرضية من قبل القائم على الإختبار.

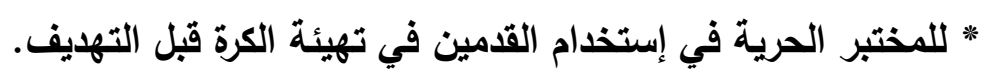

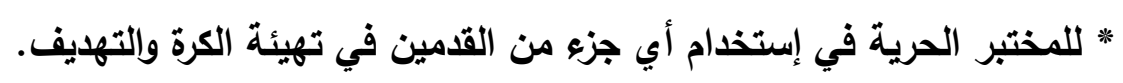

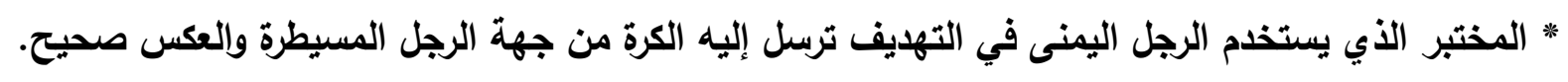

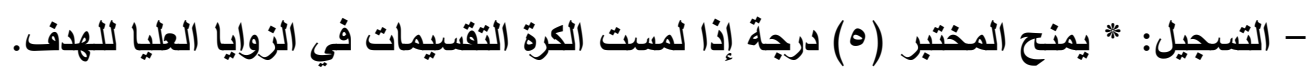

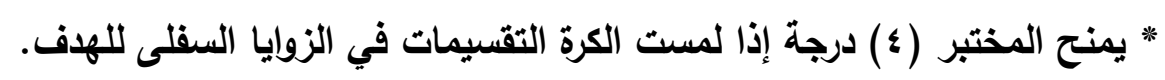

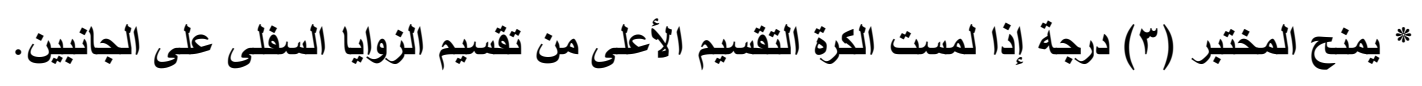

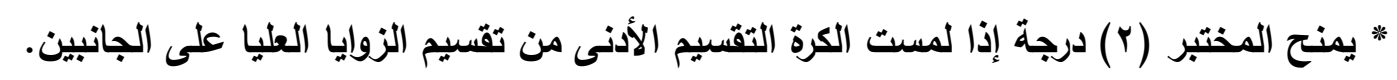

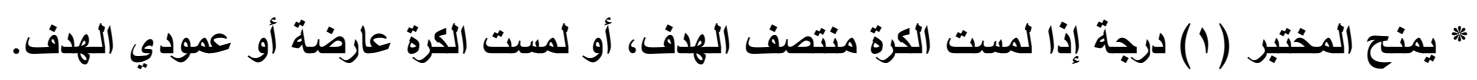

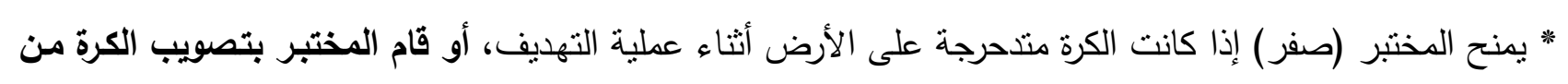
خارج منطقة الإخماد.

* في حالة خروج الكرة خارج المنطقة المحدة من قبل المرسل قبل التهايف تعاد المحاولة.

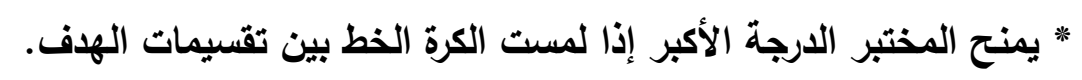

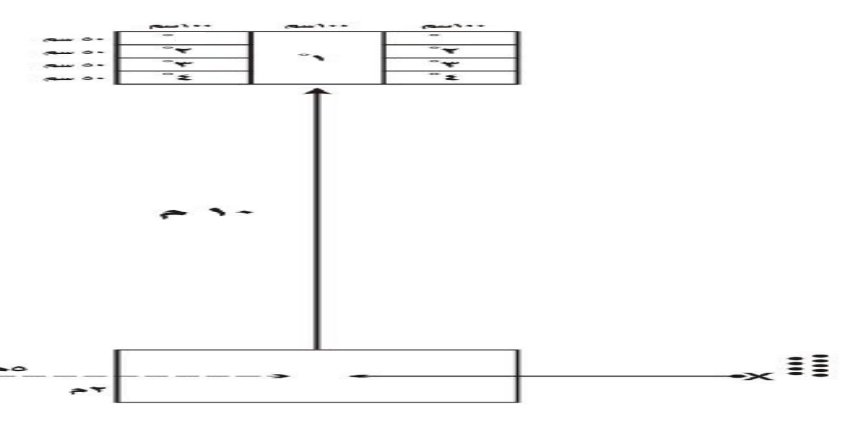
* الارجة الكلية للإختبار هي ( • ( ) درجة.

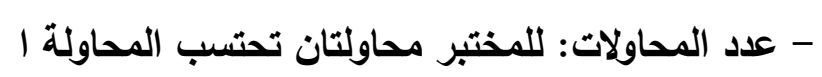

الثكل رقم (•) اختبار التهايف من الحركة من الكرة القادمة من جانب الرجل المسيطرة

الوصف الإحصائي لإختبار: التهايف من الحركة من الكرة القادمة من جانب الرجل المسيطرة.

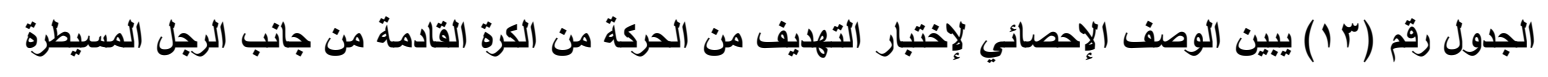




\begin{tabular}{|c|c|c|c|c|}
\hline كا' & الإلتواء & المنوال & $\varepsilon \pm$ & س \\
\hline$r, q \leq r$ & $\cdot, \cdot r$ & Y & $\{, \infty 0$ & $r q, 1 V$ \\
\hline
\end{tabular}

من خلال الجدول رقم (r I) نستدل أن: الإختبار ملائم لمستوى العينة، ويقترب من التوزيع الطبيعي مما يجعله إختباراً يمكن الإعتماد عليه في تعميم النتائج.

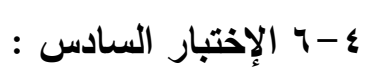

- اسم الإختبار: التهايف من الحركة من الكرة القادمة من الخلف. - الهذف من الاختبار: قياس دقة التهديف من الحركة من الكرة القادمة من الخلف للاعبي خماسي كرة القدم. - الأدوات المستخدمة: ( • () كرات خاصة بخماسي كرة القدم، هدف خاص بخماسي كرة القدم.

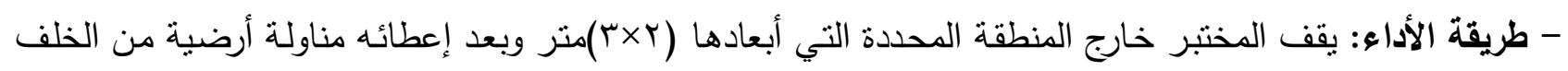

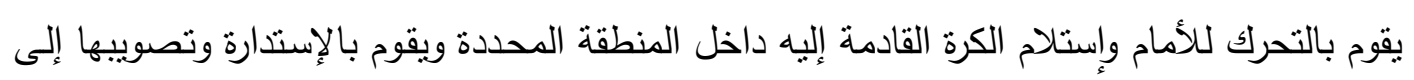

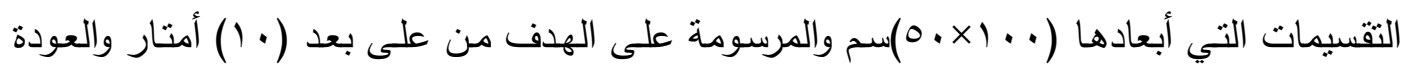

إلى نقطة البداية، وهكذا يقوم المختبر بتصويب (• (1) كرات، وكما هو موضح في الثكل رقم (؟).

- شروط الاختبار:

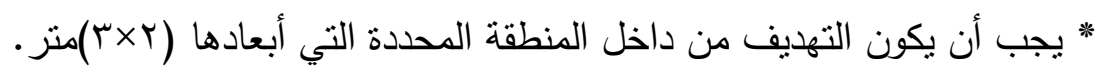
* يجب أن يكون المختبر خارج المنطقة المحدة قبل إرسال الكرة إليه من على بعد (0) أمتار .

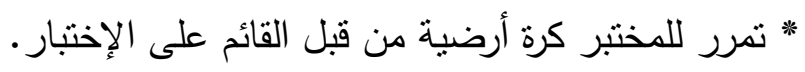
* للمختبر الحرية في إستخدام القدمين في تهيئة الكرة قبل التهديف. * للمختبر الحرية في إستخدام أي جزء من القدمين في تهيئة الكرة والتهديف. - التسجيل: -

* يمنح المختبر (0) درجة إذا لمست الكرة التقسيمات في الزوايا العليا للهدف. * يمنح المختبر (ع) درجة إذا لمست الكرة التقسيمات في الزوايا السفلى للهدف. * يمنح المختبر (ب) درجة إذا لمست الكرة التقسيم الأعلى من تقسيم الزوايا السفلى على الجانبين. * يمنح المختبر (Y) درجة إذا لمست الكرة التقسيم الأدنى من تقيم الزوايا العليا على الجانبين.

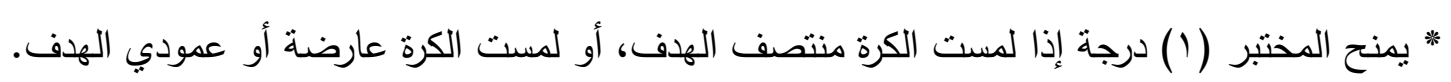
* يمنح المختبر (صفر) إذا كانت الكرة متذحرجة على الأرض أثناء عملية التهديف، أو قام المختبر بتصويب الكرة من خارج منطقة الإخماد.

* يمنح المختبر الدرجة الأكبر إذا لمست الكرة الخط بين تقسيمات الهدف. * في حالة خروج الكرة خارج المنطقة المحددة من قبل المرسل قبل التهيف تعاد المحاولة. * الدرجة الكلية للإختبار هي ( • م) درجة. - عدد المحاولات: للمختبر محاولتان تحتسب المحاولة الأفضل.

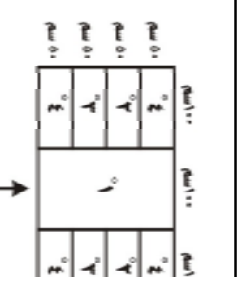


الشكل رقم (7) يوضح إختبار التهايف من الحركة من الكرة القادمة من الخلف

الوصف الإحصائي لإختبار: التهايف من الحركة من الكرة القادمة من الخلف.

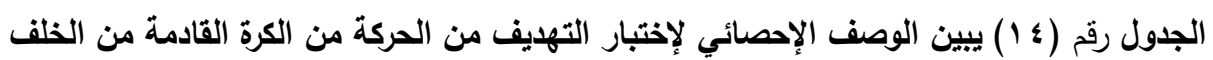

\begin{tabular}{|c|c|c|c|c|}
\hline كا' & الإلتواء & المنوال & $\varepsilon \pm$ & س \\
\hline 0,919 & $\cdot, \leqslant q-$ & rq & $\varepsilon, Y_{0}$ & $r 7,9 r$ \\
\hline
\end{tabular}

من خلال الجدول رقم (ع () نستدل أن: الإختبار ملائم لمستوى العينة، ويقترب من التوزيع الطبيعي مما يجعله

إختباراً يمكن الإعنماد عليه في تعميم النتائج.

$$
\text { : الاختبار السابع : }
$$

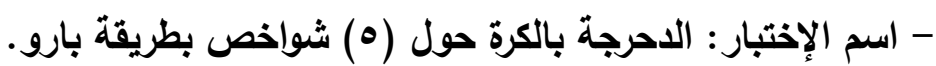
- الهرف من الاختبار : قياس الدحرجة بالكرة حول (0) شواخص بطريقة بارو للاعبي خماسي كرة القدم.

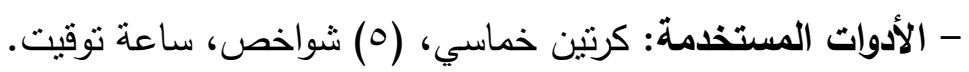

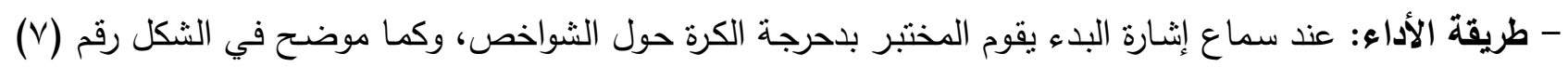
بأسرع وقت ذهاباً وإياباً.

- شروط الاختبار: * يجب أن يبدأ المختبر بالدحرجة من خلف خط البداية وعند سماع إثشارة البدء. * يجب أن يجتاز المختبر خط النهاية مع الكرة. * للمختبر الحرية في إستخدام أي من القدمين في عملية الدحرجة وفي أي جزء من القدم.

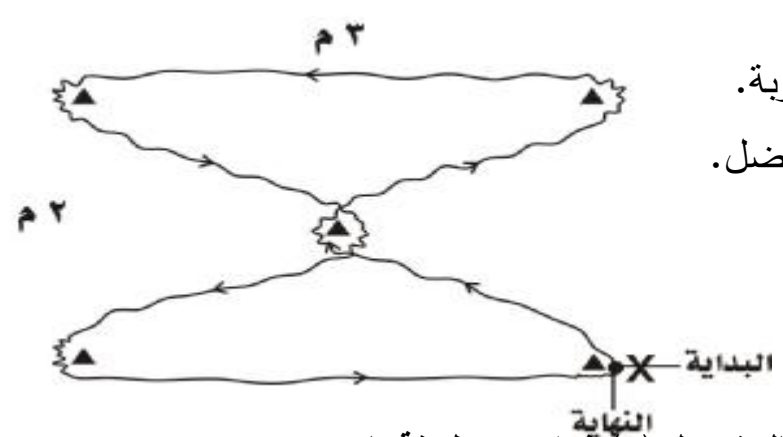

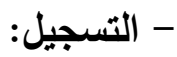
الثكل رقم ( v ) إختبار الاحرجة بالكرة حول (ه) شُّواخص بطريقة بارو

الوصف الإحصائي لإختبار : الاحرجة بالكرة حول (0) شواخص بطريقة بارو.

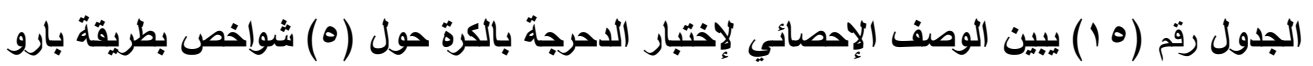

\begin{tabular}{|c|c|c|c|c|}
\hline كا'r & الإلتواء & المنوال & $\varepsilon \pm$ & س \\
\hline
\end{tabular}




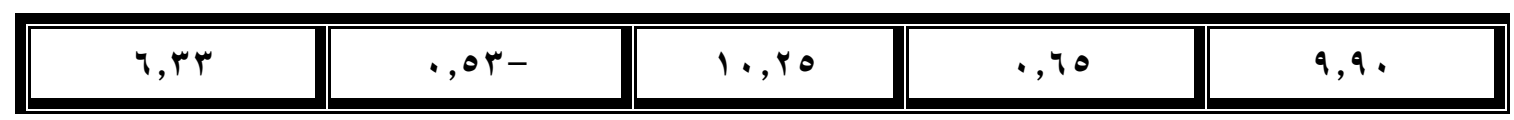

من خلال الجدول رقم (0 1) نستدل أن: الإختبار ملائم لمستوى العينة، ويقترب من التوزيع الطبيعي مما يجعله

إختباراً يمكن الإعتماد عليه في تعميم النتائج.

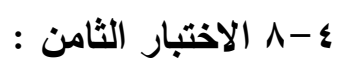

- اسم الإختبار: الاحرجة بالكرة حول (؟) شواخص بأبعاد مختلفة ذهاباً وإياباً.

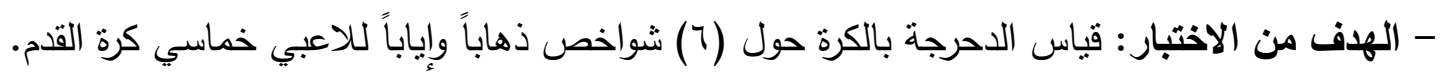

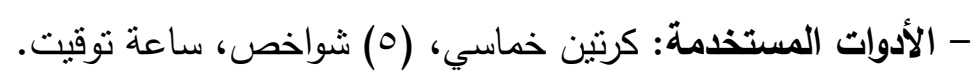

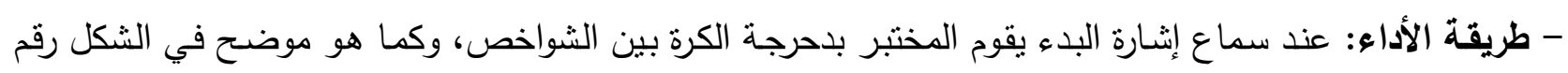
(^)

$$
\text { - شروط الاختبار : مهابا. }
$$

* يجب أن يبدأ المختبر بالاحرجة من خلف خط البداية وعند سماع إثنارة البدء. * يجب أن يجتاز المختبر خط النهاية مع الكرة. * للمختبر الحرية في إستخدام أي من القدمين في عملية الدحرجة وفي أي جزء من القدم. - التسجيل: -

* يسجل للمختبر الوقت الذي يستغرقه لقطع المسافة المطلوبة - عدد المحاولات: للمختبر محاولتان تحتسب المحاولة الأفضل.

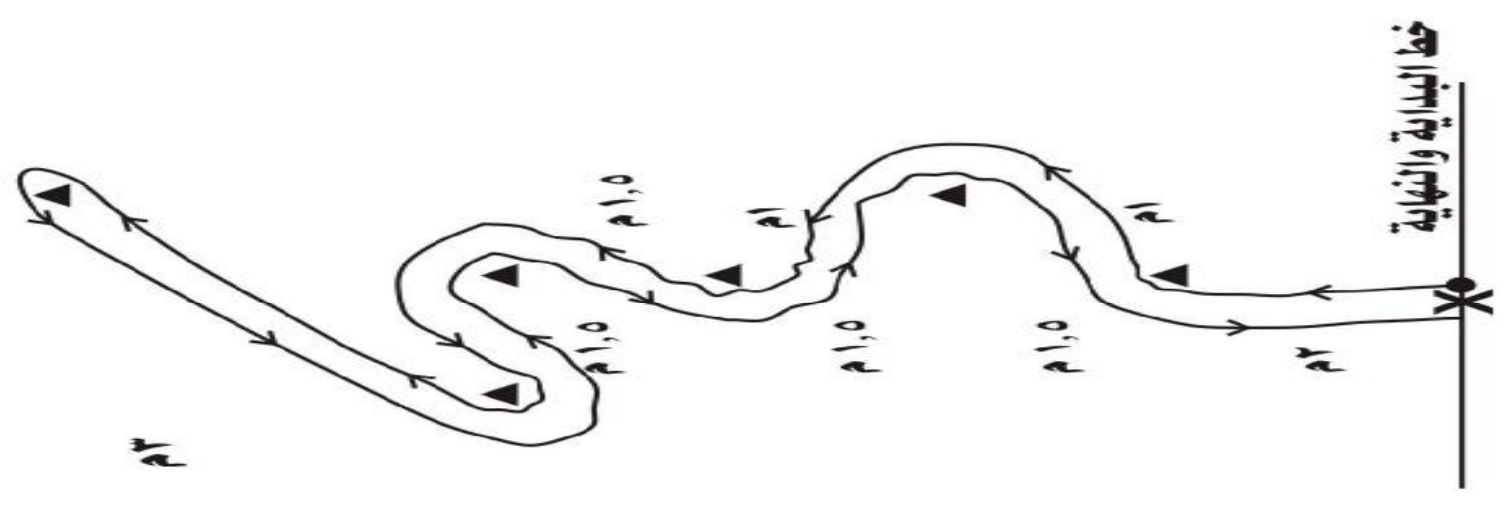

الثكل (^) إختبار الاحرجة بالكرة حول (†) شواخص بأبعاد مختلفة ذهابا وإيابا

الوصف الإحصائي لإختبار: الاحرجة بالكرة حول (†) شواخص بأبعاد مختلفة ذهاباً وإياباً.

الجدول رقم (7 1 ) يبين الوصف الإحصائي لإختبار الاحرجة بالكرة حول (†) شواخص بأبعاد مختلفة ذهاباً وإياباً

\begin{tabular}{|c|c|c|c|c|}
\hline كا' & الإلتواء & المنوال & $\varepsilon^{ \pm}$ & س \\
\hline$V, V \backslash \mathrm{T}$ & $\cdot, \diamond V$ & IV, & $1, r$. & \& \\
\hline
\end{tabular}


من خلال الجدول رقم (7 (1) نستدل أن: الإختبار ملائم لمستوى العينة، ويقترب من التززيع الطبيعي مما يجعله إختباراً يمكن الإعتماد عليه في تعميم النتائج.

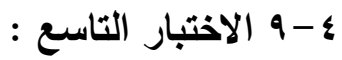

- اسم الإختبار: تمرير كرة أرضية من الاحرجة على مسطبة مقسمة.

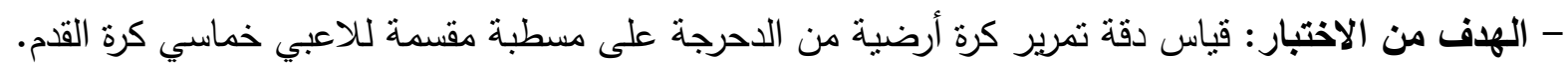

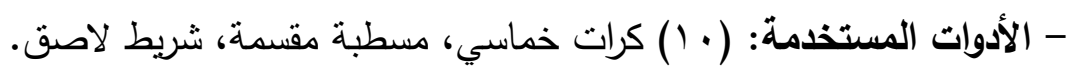

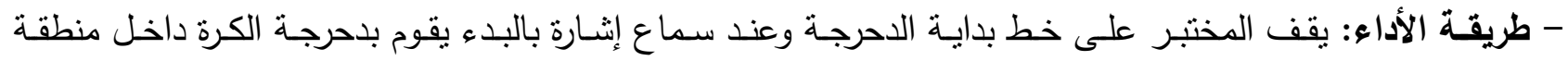

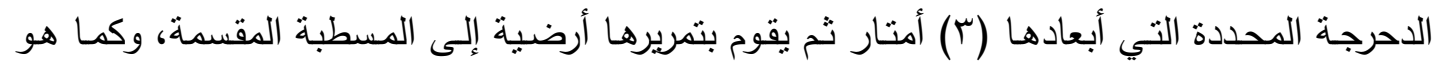

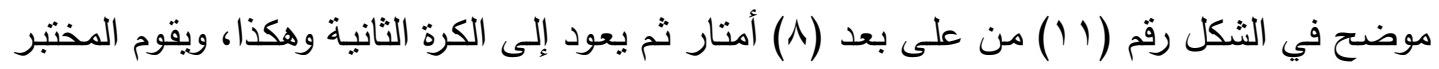

$$
\text { بتمرير (·) (1) كرات. }
$$

- شروط الاختبار: - مبر * " يجب أن تكون التمريرة أرضية. " كل الكرات توضع على خط بداية الدحرجة.

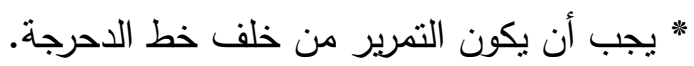
* للمختبر الحرية في إستخدام أب من القدمين في عملية الدحرجة والتمرير وفي أي جزء من القدم.

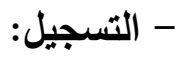
* يمنح المختبر (r) درجة إذا لمست الكرة المربع في المنتصف.

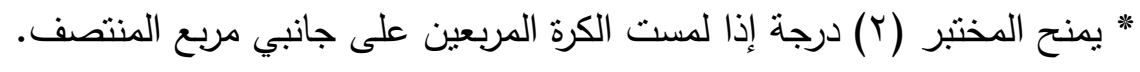
* *منح المختبر (1) درجة إذا لمست الكرة المربعين إلى الجانبين. * " لا يمنح المختبر أي درجة إذا لم تلمس الكرة المسطبة المقسمة.

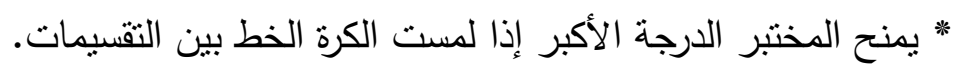

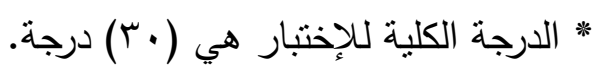

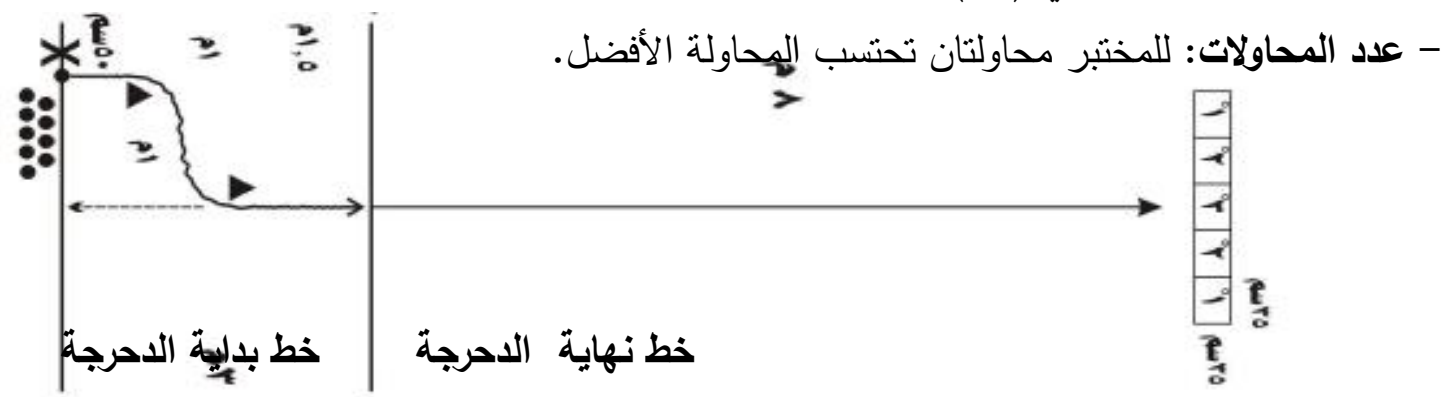

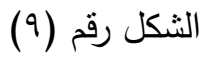

يوضح إختبار تمرير كرة أرضية من الدحرجة على مسطبة مقسمة

الوصف الإحصائي لإختبار : تمرير كرة أرضية من الدحرجة على مسطبة مقسمة.

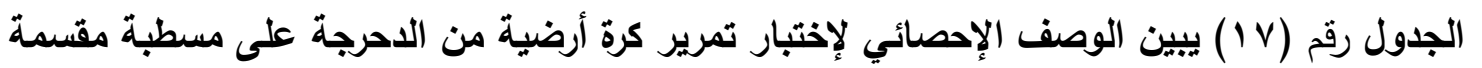




\begin{tabular}{|c|c|c|c|c|}
\hline كا' & الإلتواء & المنوال & $\varepsilon \pm$ & س \\
\hline$\Lambda, \vee q r$ & • & rY & $r, 1 r$ & r I, IV \\
\hline
\end{tabular}

من خلال الجدول رقم (V ) نستدل أن: الاختبار ملائم لمستوى العينة، ويقترب من التوزيع الطبيعي مما يجعله

اختبارا يمكن الاعتماد عليه في تعميم النتائج.

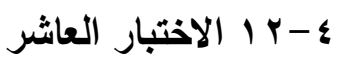

- اسم الإختبار: تمرير الكرة على الدوائر المتداخلة المرسومة على الحائط من الكرات الثابتة. - الهـدف مـن الاختبـار: قياس دقـة تمرير على الدوائر المتذاخلة المرسومة على الحائط مـن الكرات الثابتة للاعبي خماسي كرة القدم.

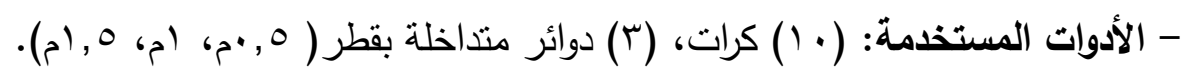
- طريقة الأداء: يقوم المختبر بتمرير (• (1) كرات ثابتة إلى الدوائر المرسومة على الحائط من خلف الخط المحدد من على بعد (• (1) أمتار، وكما هو موضتح في الثكل رقم (Y ( ).

- شروط الاختبار:

* يجب أن يكون تمرير الكرة من على خط البداية. * للمختبر الحرية في إستخدام أبي من القدمين في التمرير وفي أي جزء من القدم. - التسجيل: -

* يمنح المختبر (ب) درجة إذا لمست الكرة الدائرة الصغيرة.

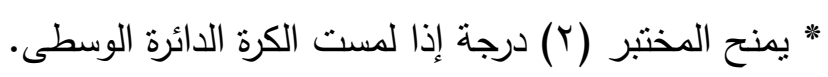

* "منح المختبر (1) درجة إذا لمست الكرة الدائرة الكبيرة.

* يمنح المختبر (صفر) إذا خرجت الكرة خارج الدوائر ، أو كانت الكرة متححرجة على الأرض أثناء عملية التمرير .

: * يمنح المختبر الدرجة الأكبر إذا لمست الكرة الخط بين الدوائر . * الدرجة الكلية للإختبار هي ( • آب) درجة.

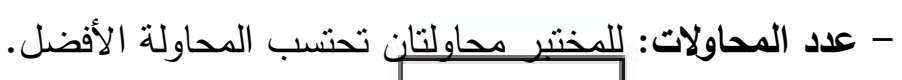

الثكل رقم (• (1)يوضح إختبار تمرير الكرة على الدوائر المتداخلة المرسومة على الحائط من الكرات الثابتة

الوصف الإحصائي لإختبار: تمرير الكرة على الدوائر المتداخلة المرسومة على الحائط من الكرات الثابتة. الجدول رقم (1 () يبين الوصف الإحصائي لإختبار تمرير الكرة على الدوائر المتداخلة المرسومة على الحائط من الكرات الثابتة

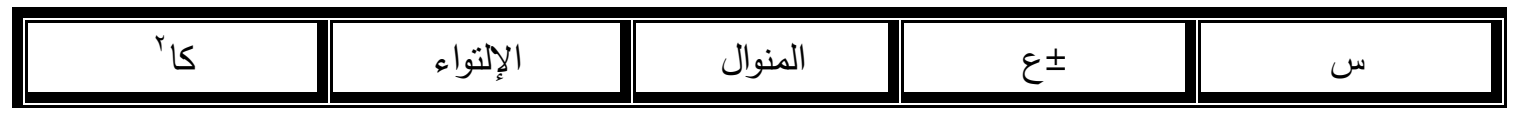




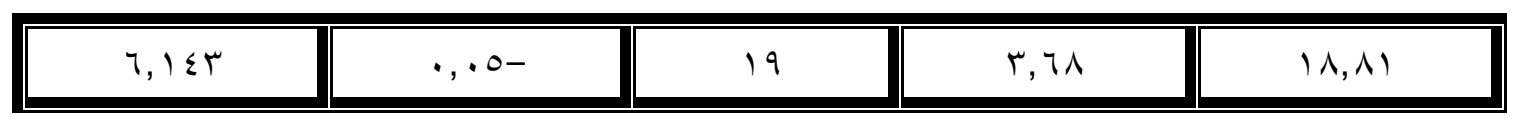

من خلال الجدول رقم (1 () نستذل أن: الإختبار ملائم لمستوى العينة، ويقترب من التوزيع الطبيعي مما يجعله إختباراً يمكن الإعنماد عليه في تعميم النتائج. ه - الاستنتاجات والتوصيات والمقترحات :

: - 0

ا. نتيجةً لأتباع الوسائل العلمية الخاصة بيناء الإختبارات تم الحصول على مجموعة إختبارات مهارية للاعبي خماسي كرة القدم تتمتع بمعاملات علمية جيدة من صدق وثبات وموضوعية وتوزيع طبيعي وهي: - تمرير الكرة بالقدم من الدحرجة لمدة (• بـ ثنانية - تمرير كرة أرضية بالقدم من الدحرجة على مسطبة مقسمة.

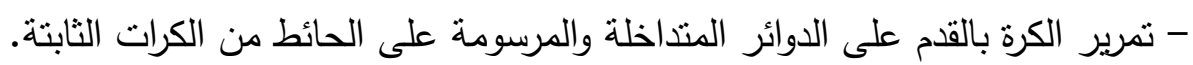
- التهديف من الحركة على التقسيمات المتداخلة والمرسومة داخل الهدف. - التهديف من الكرات الثابتة على ستة تقسيمات. - التهديف من الحركة.

- التهديف من الحركة من الكرة القادمة من جانب الرجل المسيطرة. - التهديف من الحركة من الكرة القادمة من الخلف. - الدحرجة بالكرة حول (0) شواخص بطريقة بارو . - الدحرجة بالكرة حول (7) شواخص بأبعاد مختلفة ذهاباً وإياباً. r. تم رفض مجموعة إختبارات لعدم تحقيقها الأسس العلمية للإختبار وهذه الإختبارات هي: - الدحرجة بالكرة حول (^) شواخص بأبعاد مختلفة ذهاباً وإياباً. - الدحرجة بالكرة حول منلث متساوي الأضلاع. - التهديف من الكرات الثابتة.

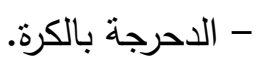
- الاحرجة بالكرة حول (9) شوهوه باخص. وذلك لعدم حصولها على نسبة إتفاق (1\%00) من آراء السادة الخبراء. ـ. الاختبارات المعتمدة تتوزع توزيعاً طبيعياً.

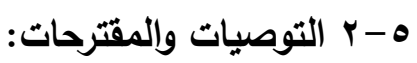
يوصي الباحثان ب: ا ـ اعتمـاد الإختبارت التي حققت الأسـس العلميـة من صـدق وثبـات وموضـوعية وتوزيـع طبيعي في تقويم المهارات الأساسية للاعبي خماسي كرة القدم. 


\section{تصميم وبناء اختبارات لقياس بعض المهارات الأساسية للاعبي أندية الدوري الممتاز العراتي....}

r. الاستفادة من هذه الإختبارات في مجالات أخرى عند وضع البرامج التندريبية أو انتقاء اللاعبين خدمةً لهذه اللعبة. r. باء باء إختبارت أخرى غير الإختبارات المستخدمة في البحث.

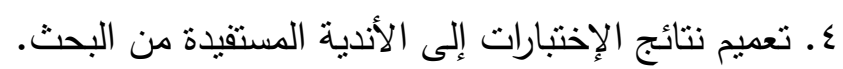

$$
\text { ه. إجراء بحوث مشابهة على عينات أخرى. }
$$

7. إجراء بحوث مثابهة على مناطق جغرافية أخرى.

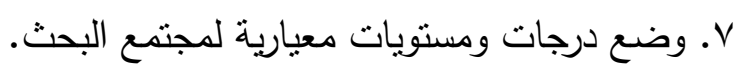

المصادر العربية والأجنبية: - n

• باهي، مصطفى حسين (1999) (199 المعاملات العلمية العملية بين النظرية والتطبيق، طا، مركز الكتاب للنشر ، القاهرة. بلوم، بنيامين وآخرون (r/91 ()): تقييم تعلم الطالب التجميعى والتكويني، ترجمة: محمد أمين المفتي وآخرون،

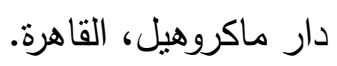

الخشاب، زهير قاسم وآخران (•99 (19): تصميم وتقنين إختبارات لقياس بعض المهارات الحركية الأساسية بكرة

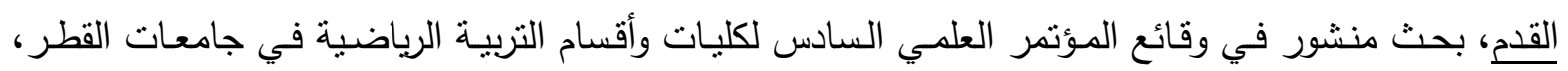

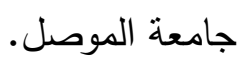

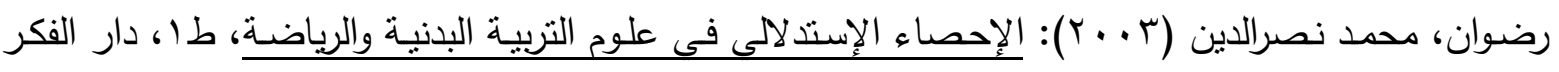

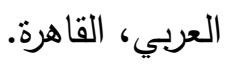

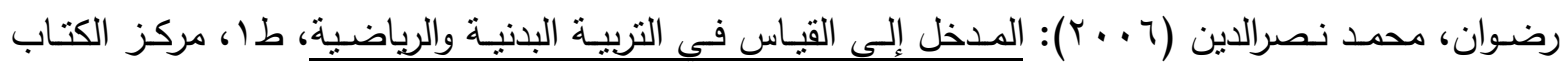

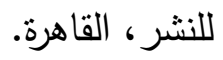

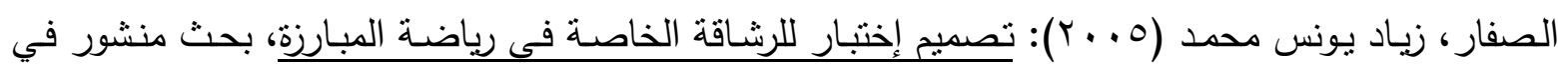

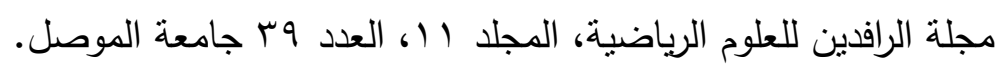

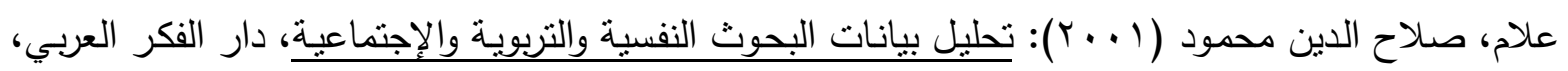
القاهرة. علاوي، محمد حسن ورضوان، محمد نصرالدين (9V9 (1)): القياس في التربية الرياضية وعلم النفس الرياضى،

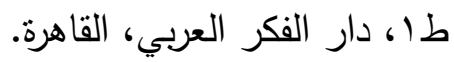
علاوي، محمد حسن ورضوان، محمد نصرالدين (9AV (1)): الإختبارات المهارية والنفسية في المجال الرياضي، طا، دار الفكر العبي، القاهرة.

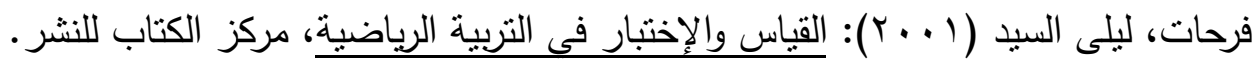

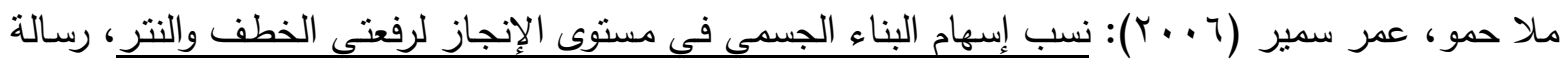
ماجستير غير منشورة، كلية التربية الرياضية، جامعة الموصل.

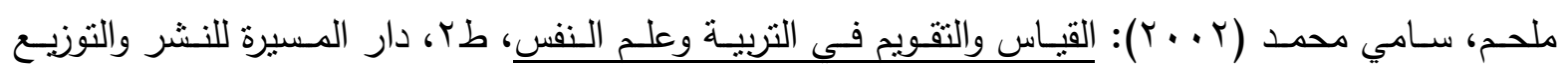
والطباعة، عمان، الأردن. المندلاوي، قاسم وآخران (919 (19): الإختبارات والقياس والثقويم في التربية الرياضية. 


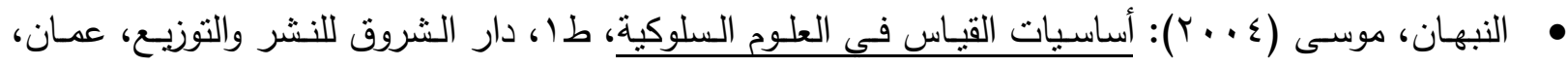

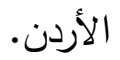

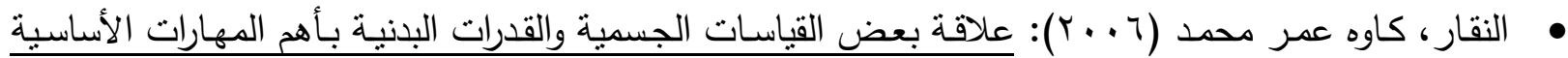

للاعبات خماسى كرة القدم، رسالة ماجستير غير منشورة، كلية التربية الرياضية، جامعة كويه.

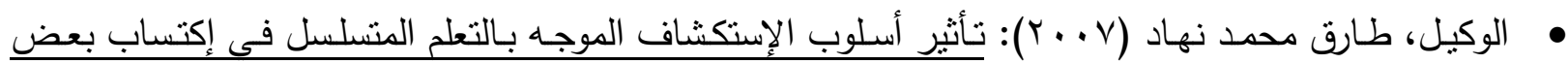
المهارات الحركية بخماسى كرة القدم، رسالة ماجستير غير منشورة، كلية التربية الرياضية، جامعة ديالى.

- . (1978):

- SPOKANE FUTSAL OVERVIEW. HTM.

- WWW. HOLISTICSOCCR. COM.

الملحق ( (1)يبين تحليل المهارات الأساسية لفعالية خماسي كرة القدم

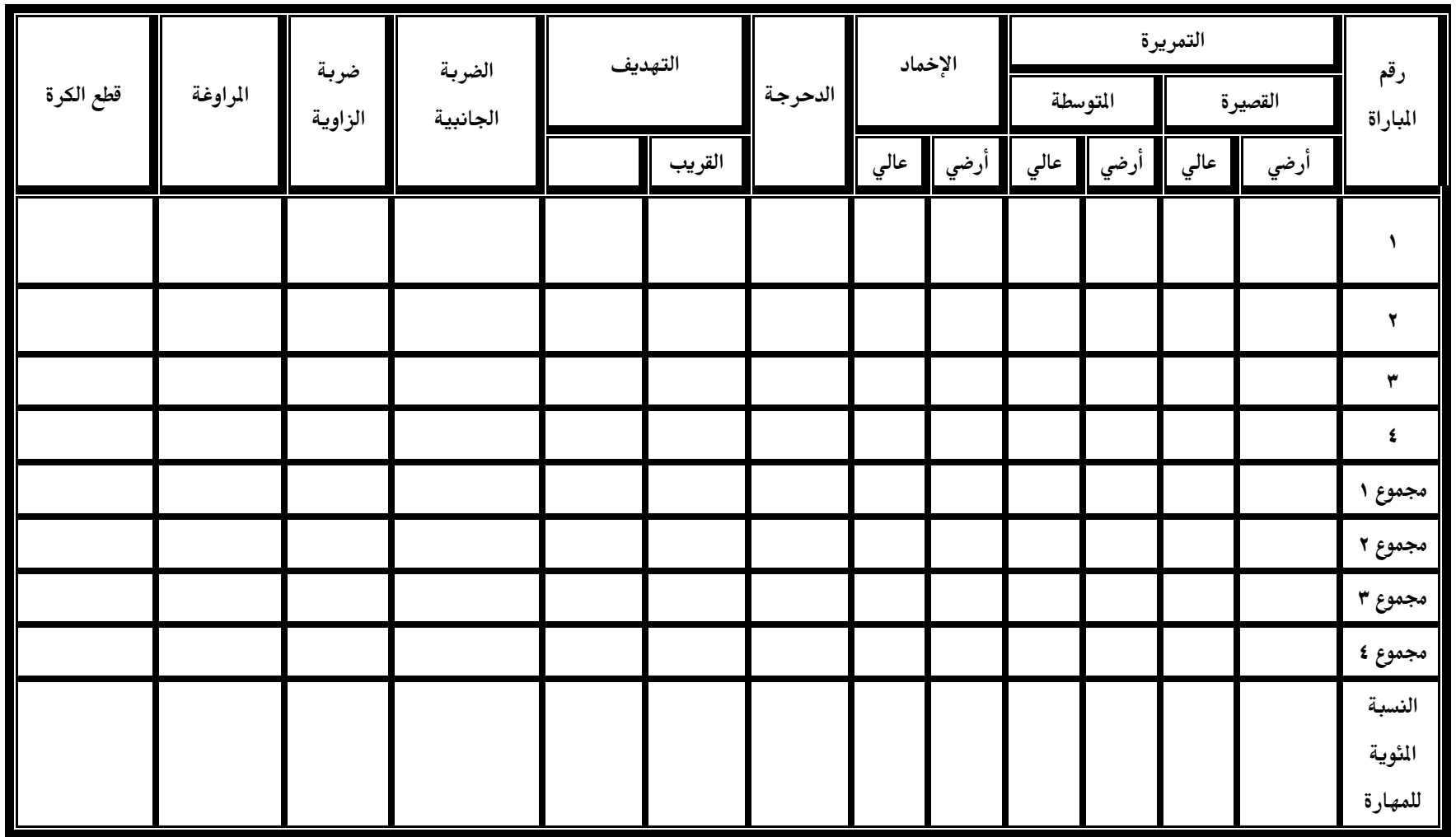

ملدق (ץ) إستمارة عرض الإختبارات على السادة الخبراء

$$
\text { كلية التربية الرياضية }
$$

م/ استمارة استبيان

المحترم

الأستاذ الفاضل 
في النية إجراء البحث الموسوم بـ (بناء اختبارات لقياس بعض المهارات الأساسية للاعبي خماسي كرة القدم) ولكونكم

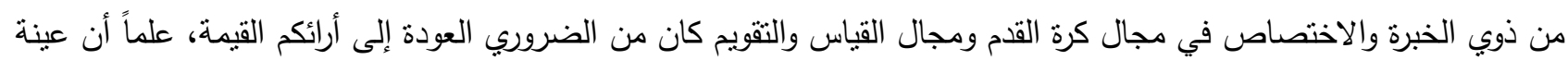
البحث هم من لاعبي الدوري العراقي للارجة المتازة في المنطقة الثمالية. يرجى من سيادتكم بيان مدى صدئ صلاحية الاختبارات مع الامتتان والتقدير لجهودكم .... والله الموفق.........

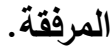

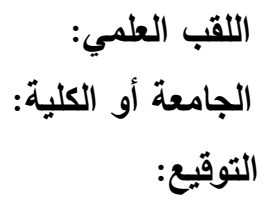

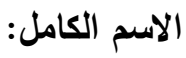

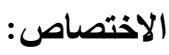

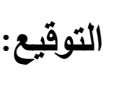$$
\text { التاريخ: }
$$$$
\text { ملاحظة : يرجى ملاحظة رموز الاختبارات وكالاتي : }
$$

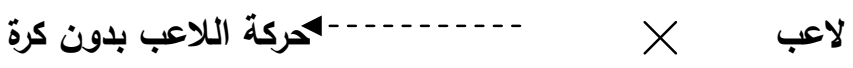$$
\text { مناولة }
$$$$
\text { كرة }
$$

الاحرجة بالكرة

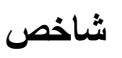

\begin{tabular}{|c|c|c|c|}
\hline يصلح بعد لتعديل & 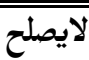 & يصلح & أسماء الاختبارات \\
\hline & & & التهديف ستة تقسيمات. \\
\hline & & & التهديف من الحركة. \\
\hline & & & التهديف من الكرات الثابتة. \\
\hline & & & التهديف من الحركة من الكرة الجانبية. \\
\hline & & & التهديف من الحركة على التقسيمات المتداخلة. \\
\hline & & & | التمرير على دوائر مرسومة.. \\
\hline & & & الدحرجة بالكرة حول (9) شواخص. \\
\hline & & & الدحرجة بالكرة حول مربع. \\
\hline & & & الدحرجة بالكرة حول مثلث. \\
\hline & & & الدحرجة بالكرة حول (0) شواخص. \\
\hline & & & الدحرجة بالكرة حول (^) شواخص. \\
\hline & & & تمرير الكرة لمدة (•r) ثانية من الحركة. \\
\hline & & & تمرير الكرة على مسطبة. \\
\hline & & & تمرير الكرة على (ع) أهداف. \\
\hline & & & التهديف من الحركة من الكرة القادمة من الجانب \\
\hline & & & التهديف من الحركة من الكرة القادمة من الخلف \\
\hline & & & الدحرجة بالكرة حول (ه) شواخص بطريقة بارو. \\
\hline & & & الدحرجة بالكرة حول(؟) شواخص بأبعاد مختلفة ذهابا وإيابا \\
\hline
\end{tabular}

